\title{
Praia dos Ingleses 1: Arqueologia subaquática na Ilha de Santa Catarina, Brasil (2004/2005/2009)*
}

\author{
Francisco Silva Noelli** \\ Alexandre Viana*** \\ Marcelo Lebarbenchon Moura ***
}

\begin{abstract}
NOELLI, F.S.; VIANA, A.; MOURA, M.L. Praia dos Ingleses 1: Arqueologia subaquática na Ilha de Santa Catarina, Brasil (2004/2005/2009). Revista do Museu de Arqueologia e Etnologia, São Paulo, 19: 179-203, 2009.
\end{abstract}

Resumo: $\mathrm{O}$ artigo apresenta a metodologia e alguns resultados preliminares da pesquisa de arqueologia subaquática realizada em dois períodos: entre março de 2004 e fevereiro de 2005, e entre fevereiro e maio de 2009, no sítio Praia dos Ingleses 1, na Ilha de Santa Catarina, Brasil.

Palavras-chave: Arqueologia Subaquática - Arqueologia Histórica - História Colonial do sul do Brasil.

- Projeto de Arqueologia Subaquática, financiado pela Fundação de Apoio à Pesquisa do Estado de Santa Catarina (Convênio n. 01/2004 e n. 18.350/2008-4); autorizado pela Marinha do Brasil (Portaria n. 59/DPC, de 03/06/2003 - D.O.U. n. 11, seção 1, p. 7, de 16/01/2004). Contrato de Autorização (n. 52.000/2003-015/00 - DPC/Marinha do Brasil), acordado no dia 16/12/2003, entre a autoridade naval, ministro da cultura e o PAS. Projeto desenvolvido em convênio de colaboração científica com a Universidade do Vale do Itajaí - UNIVALI/SC e com o Museu Casa do Homem do Mar/município de Bombas.

(**) Arqueólogo, mergulhador. Professor aposentado da Universidade Estadual de Maringá.ffnoelli@wnet.com.br $\left.{ }^{(* *}\right)$ Arquiteto, mergulhador. dolito@ig.com.br $(* * *)$ Geógrafo, mergulhador. mouraresgate@brturbo.com.br

de uma embarcação naufragada. Os desdobramentos dessa atividade são a curadoria, o estudo dos artefatos e a criação de um museu local destinado a incentivar a preservação do patrimônio cultural. O desenvolvimento de estudos sobre história naval, cultura material, conservação de artefatos, tecnologia náutica, economia marítima, história e cultura dos trabalhadores do mar, também integram a agenda do PAS (Viana, Correa, Moura 2004).

Este artigo apresenta os resultados da escavação de $220 \mathrm{~m}^{2}$ realizada entre março de 2004/abril de 2005 e fevereiro/maio de 2009. Ainda não são conhecidas a data do afundamento e tampouco a identidade da embarcação. Contudo, a análise dos artefatos e a pesquisa histórica indicam que o naufrágio ocorreu em 1687, que o barco apresenta técnicas construtivas espanholas e que, ademais, foi capturado por piratas que saqueavam a zona costeira do Pacífico, entre o Chile e o México. 
Nossa pesquisa não ocorre em um sítio com o casco exposto na superfície do leito marinho, em águas tranqüilas e transparentes. $\mathrm{O}$ registro arqueológico está totalmente enterrado e a estratégia de campo é determinada pelo ambiente de praia, cuja dinâmica inconstante limita a área de escavação a $4 \mathrm{~m}^{2}$, excepcionalmente de 8 a $12 \mathrm{~m}^{2}$, e dificulta a visualização, o registro, e atrasa a obtenção de dados para responder perguntas sobre: 1) formação do registro arqueológico; 2) causa do naufrágio; 3) classe de barco; 4) composição da carga; 5) tripulação e passageiros etc. $\mathrm{O}$ ambiente obrigou a dividir a escavação em duas etapas distintas: 1) o registro e a remoção de elementos pequenos (lastro, concreções, fragmentos cerâmicos etc.); 2) o registro e a remoção dos elementos estruturais do casco, liberados do imenso peso e volume dos itens pequenos. Entre as duas etapas, intencionalmente cobrimos as partes estruturais com sedimento para protegê-las da fauna marinha, ressacas e antropia. A camada arqueológica é difícil de escavar, pois é composta por toneladas de seixos de lastro que rolaram sobre parte da carga quando o barco colapsou.

\section{A posicão do sítio arqueológico}

Em termos logísticos, a posição do sítio facilita a segurança da equipe e a pesquisa arqueológica, no setor sudeste da enseada da Praia dos Ingleses, norte da Ilha de Santa Catarina, litoral sul do Brasil (Fig. 1). Dispensa o serviço totalmente embarcado e a maior parte do equipamento pesado fica em terra. Está a $70 \mathrm{~m}$ da praia e a $10 \mathrm{~m}$ do costão rochoso, entre as coordenadas $27^{\circ} 26^{\prime} 12^{\prime \prime} / 27^{\circ} 26^{\prime} 14^{\prime \prime} \mathrm{S}$ e $48^{\circ} 22^{\prime} 35^{\prime \prime} / 48^{\circ} 22^{\prime} 37^{\prime \prime W}$, ocupando uma área estimada de $600 \mathrm{~m}^{2}$ sob uma coluna média com $2 \mathrm{~m}$ de água. A visibilidade varia entre 0 e 6 metros, com média de $80 \mathrm{~cm}$. A temperatura varia entre 13 e 27 graus Celsius, com média de $18^{\circ}$. Nas imediações estão as dunas das Aranhas, depósitos eólicos que alimentam com sedimentos a enseada quando ocorrem ventos do quadrante Sul.

\section{A formação do registro arqueológico}

O naufrágio compreende o afundamento e a deposição no leito subaquático de um conjunto de artefatos e, eventualmente, seres vivos. Considerando o processo de formação do registro arqueológico (Schiffer 1987), o naufrágio possui uma etapa deposicional e outra pós-deposicional. Na primeira etapa artefatos e seres vivos dentro de um sistema fechado, ordenado e dinâmico (o barco), sofrem um colapso que resulta na deposição no leito subaquático. Na etapa pós-deposicional o barco e seu lugar configuram o sítio arqueológico, que entra em relativo estado de equilíbrio com o ambiente, onde alguns tipos de artefatos ficam preservados e outros tendem a desaparecer por processos químicos, físicos e biológicos. As condições ambientais mudam e pode haver desequilíbrio e rápida deterioração de materiais que sobreviveram por centenas de anos (Delgado \& Staniford 2002).

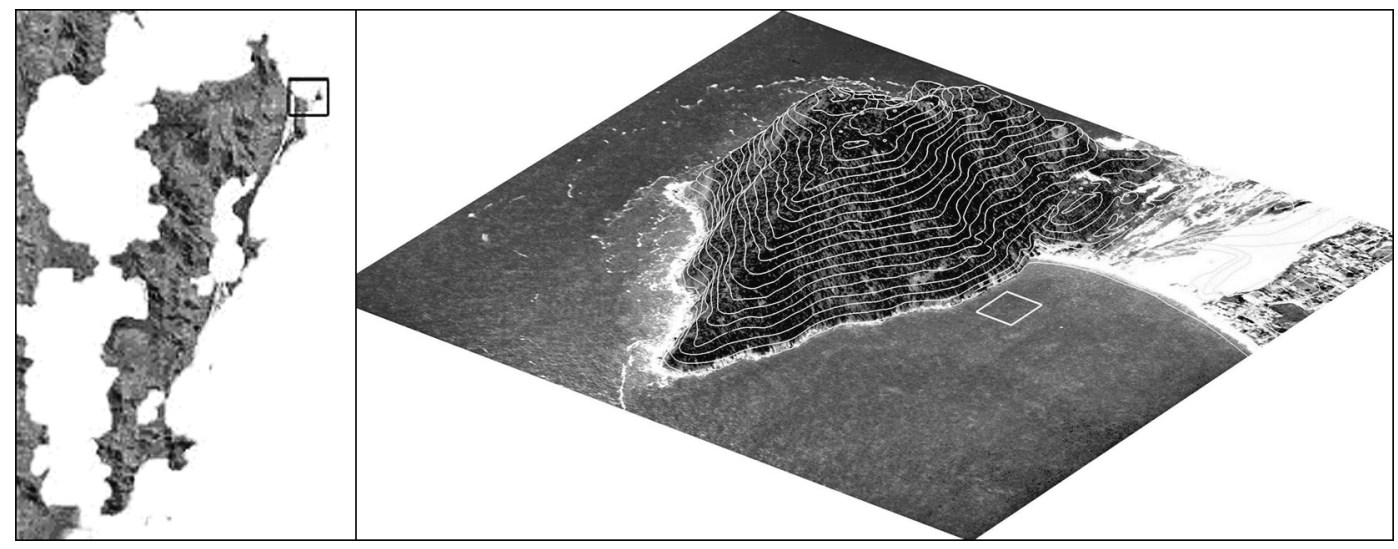

Fig. 1. Localização do Sítio Arqueológico Praia dos Ingleses 1. 
Muckelroy (1978:157-159) estabeleceu os parâmetros para compreender o processo de transformação de um barco naufragado em sítio arqueológico, sugerindo variáveis deposicionais e pós-deposicionais. Para ele, a evolução do naufrágio possui as seguintes variáveis (incluindo a perda de elementos embarcados pela própria dinâmica do sinistro, salvatagem etc.): 1) processo de afundamento (pessoas e materiais flutuam e saem da embarcação); 2) operações de salvatagem após o colapso (resgate de corpos humanos e materiais); 3) desintegração dos perecíveis; 4) movimento do leito marinho; 5) materiais depositados subsequentemente no local do naufrágio; 6) características da escavação arqueológica; 7) observação da topografia do leito marinho. Os dois primeiros itens integram a pesquisa quando há relatos do afundamento e se pessoas e parte da carga foram salvas. $\mathrm{O}$ terceiro item só pode ser avaliado com maior precisão quando é possível comparar o conteúdo do registro arqueológico com o manifesto da carga, lista da matalotagem, lista de passageiros e o memorial descritivo do barco. Os itens 4 e 5 devem-se a aspectos ambientais específicos levantados em campo. Os itens 6 e 7 dependem dos pesquisadores, especialmente da perícia para escavar o registro arqueológico com baixo impacto. Muckelroy (1978:161-165) sugeriu a coleta de dados do local de inserção do sítio arqueológico para: 1) avaliar a sobrevivência arqueológica e os elementos ambientais; 2 ) estabelecer classes de naufrágios. O tipo de sítio do naufrágio, de acordo com Muckelroy (1978:164-165), pertence à classe 2 (apresenta elementos estruturais, elementos orgânicos, muitos objetos, distribuição espalhada-ordenada).

\section{Fontes escritas e a formação do registro arqueológico}

A maioria dos barcos europeus das companhias comerciais e do serviço estatal, depois de 1500, deixou algum rastro documental náutico, alfandegário, burocrático, militar, contábil ou pessoal. Outra parte não deixou rastros, geralmente participando de operações especiais de Estado ou para companhias privadas, como os corsários. Outros barcos não contabilizados seriam os capturados por piratas, grupos fora da lei. Eventualmente, é possível que existam registros diretos ou indiretos das testemunhas ou sobreviventes do naufrágio ou, ainda, das tradições orais. O fato é que a análise da formação do registro arqueológico de um naufrágio nem sempre incluirá dados históricos específicos.

Nossa compreensão do processo de formação do registro arqueológico do sítio Praia dos Ingleses 1 ainda é limitada às evidências da escavação. Não conseguimos localizar os dados históricos específicos e completos do barco, mas procuramos fontes do período 1680-1730 na: 1) bibliografia brasileira; 2) bibliografia internacional; 3) documentos publicados; 4) documentos inéditos em arquivos brasileiros e outros países. Estendemos o período considerando a possibilidade de encontrar informações produzidas posteriormente a 1687.

O naufrágio insere-se em um contexto histórico complexo, dentro de um leque de múltiplas variáveis, pois o litoral catarinense oferecia abrigo e abastecimento às rotas marítimas. Apesar de as técnicas construtivas do barco sugerirem origem espanhola, ele poderia estar a serviço de portugueses, holandeses, franceses, ingleses, dinamarqueses, alemães ou ser "não contabilizado". Poderia tratar-se de barco: 1) em cabotagem Brasil-Rio da Prata; 2) espanhol (militar, aviso ou registro) $)^{1}$ para o Rio da Prata ou Pacífico; 3) português na carreira das Índias; 4) europeu militar, de companhia comercial ou de armadores autônomos; 5) corsários; 6) "piratas"; 7) europeu isolado em rota aleatória. É importante ressaltar a contínua presença dos barcos do comércio triangular atlântico, que arribavam ao Rio da Prata e ao Brasil para contrabandear, usando o pretexto de tempestades ou avarias (cf. exemplos em Molina 1966).

Revisamos a bibliografia brasileira, especialmente de Santa Catarina, sem achar nenhum registro explícito sobre o sítio Praia dos Ingleses 1. A única informação existente foi publicada

(1) Navio de aviso: barco postal a serviço da Espanha que geralmente não transportava carga ou passageiros (cf. Leyes de Indias, §37). Navio de registro: barco de particular licenciado pelo Estado espanhol para comerciar por tempo determinado em colônia especifica (cf. Leyes de Indias, § 35). 
por Coelho (1856:184): "essa praia é chamada dos Ingleses por haver ali, em tempos remotos, naufragado um grande navio inglês, e que alguns vestígios ou mesmo destroços foram descobertos pelo temporal de março de 1838”. Essa referência nunca foi repetida na historiografia catarinense, ficando esquecida até agora. O levantamento arqueológico na enseada não localizou outros barcos afundados no período colonial, fator que relaciona o sítio Praia dos Ingleses 1 aos destroços noticiados por Coelho. Nem os mais velhos pescadores artesanais, cujos antepassados chegaram ali há mais de 100 anos, sabiam do naufrágio.

A época do afundamento coincide com o início do processo colonial português na região e com a fundação dos primeiros núcleos costeiros. O assentamento da Nossa Senhora do Desterro (atual Florianópolis) desenvolveu-se após 1673 e estava consolidado em 1678. Em 1689, depois de um ataque pirata, parte dos povoadores abandonou a área e a colonização só foi retomada em 1711, quando a população alcançou aproximadamente 150 "brancos" (sem contar índios e negros). Os colonos produziram poucas fontes escritas e a maior parte foi perdida. Os documentos conhecidos foram publicados na integra ou resumidamente e acreditamos que os historiadores não encontraram informações sobre o naufrágio (Boiteux 1931; Almeida 1957; Domingues 1973; Cabral 1979; Piazza 1983).

Estamos levantando a bibliografia internacional sobre naufrágios, rotas de navegação, armadores autônomos, companhias de comércio e suas diversas rotas, tráfico de escravos e outras. Trata-se de um conjunto vasto e heterogêneo de fontes a partir do século XVI (Mauro 1980, 1997), com roteiros de viagens, listas de embarcações, rotas, tripulação, passageiros, carga e a história de cada barco, cujo exemplo é o estudo das viagens da holandesa Vereenigde Oostindische Compagnie (Companhia das Índias Orientais) VOC (Bruijin, Gaastra e Schöffer 1979-1983).² Outro exemplo, mas centrado no levantamento

(2) Existe um levantamento preliminar de barcos e frotas que navegaram na costa brasileira entre 1500 e 1822 (Godoy 2007). sistemático dos naufrágios, é o estudo sobre as perdas portuguesas na carreira das Índias (Guinote et al. 1998), bastante completo sobre o período 1500-1699. Existem duas sínteses que definem o campo de estudos das navegações no Atlântico Sul, Seville et l'Atlantique (Chaunu Chaunu 1955-1960) e Portugal, o Brasil e o Atlântico (Mauro 1997), mas são lacunares para a região sul. O mesmo se aplica à História Naval Brasileira (Guedes 1975-1985), que pouco tratou da costa meridional. Existem estudos específicos que revelam o fluxo da navegação entre o Brasil e o Rio da Prata no período 15801700 , basicamente restritos aos barcos portugueses e espanhóis (Canabrava 1944; Molina 1966). Parte da solução é pesquisar documentos publicados ou inéditos. Contudo, para o minucioso conhecimento da navegação na costa brasileira e no rio da Prata é necessário pesquisar em bibliotecas e arquivos espalhados por três continentes (Mauro 1997 2:297). Para iniciar, buscamos as publicações de crônicas e documentos completos ou resumidos do período 16801730, sobre o Brasil meridional e o Rio da Prata (Noelli s.d.:1)

Algumas pesquisas revelam o grande potencial das fontes. Um exemplo é o levantamento das 35 mil viagens na era do tráfico de escravos no Atlântico, registradas no livro/CDROM The Trans-Atlantic Slave Trade e no site homônimo (Eltis et al. 1999; lacunar para o litoral sul do Brasil e Rio da Prata). Também é importe a história da VOC, que entre 1602 e 1798 construiu 1.600 embarcações, transportou 700.000 pessoas em 4.789 viagens e sofreu 105 naufrágios (Gawronski 2002:565). Outra instituição colonial holandesa foi a West-Indische Compagnie WIC (Companhia das Índias Ocidentais), que atuou entre 1621 e 1791 . Sua área de operações concentrou-se da África ocidental às Américas, entre o Trópico de Capricórnio e o Cabo da Boa Esperança. Seu objetivo era eliminar a concorrência, tomar as possessões portuguesas e suas atividades incluíam o corso. Consta que entre 1700 e 1730, a WIC teve uma frota que oscilava entre 490 e 520 barcos (Paesie 2008). Outro exemplo é a inglesa Company of Royal Adventurers Trading to Africa, criada em 1660 para traficar escravos. Em 1672 
ressurgiu como The Royal African Company (RAC), armando 249 viagens à África e às Américas entre 1680 e 1686 (Davies 1999:206). No período 1698-1709, ocorreram 601 viagens entre a Inglaterra e a África (Rawley 2003:39). Os franceses também atuaram no Atlântico Sul, com companhias comerciais e grupos de corso, chegando a capturar 45 barcos da RAC, entre 1688 e 1712 (Davies 1999:206). Entre 1713 e 1744, partiram da França 937 barcos rumo à África, mantendo sua presença no Atlântico Sul (Rawley; Behrendt 2005:118). Da Bahia à África zarparam 463 barcos portugueses entre 1680 1713 (Eltis 2000:301).

Os números mostram que o Atlântico Sul não era um deserto entre 1680-1730 e que a costa meridional do Brasil estaria na rota sistemática ou aleatória de inúmeros barcos. Nossa investigação em andamento, de mais de três mil títulos de arqueologia, história, crônicas de viagem e coleções documentos publicados, registrou 262 barcos que aportaram ou passaram ao largo da ilha de Santa Catarina neste período (média de 5,22 barcos/ano). Há cinco notícias de naufrágios entre o Paraná e Buenos Aires no período citado, mas nenhum próximo à Ilha de Santa Catarina.

Um barco sobressai como candidato ao naufrágio da Praia dos Ingleses. O historiador Amílcar D'Avila de Mello, um dos maiores especialistas da história colonial catarinense (Mello 2005), nos sugeriu a hipótese de que seria o barco de Thomas Frins, possivelmente afundado em 1687. A principal fonte dessa informação ${ }^{3}$ é a Nobiliarquia Paulistana, de Pedro Taques de Almeida (1980:85-86), que resumiu/transcreveu partes do inquérito de Frins que consta do livro de registro n. 4 da Real Fazenda de São Paulo, feito pela justiça

(3) Vários pesquisadores trataram do tema (cf. Boiteux 1931), mas nenhum acrescentou dados aos de Taques. O nome "ingleses" apareceu pela primeira vez em 1776, no mapa de José Custódio de Sá e Faria. Várzea ([1900] 1985:98) resumiu a história oral da origem do nome da Praia dos Ingleses, sobre um barco inglês que ao final do século XVIII aportou para reparos e depois partiu. Possivelmente a tradição oral, após mais de 200 anos, reduziu em um século o evento do barco de Frins. portuguesa em Santos no dia 26/02/1688 (o livro 4 desapareceu do Arquivo Público de São Paulo). São as seguintes informações:

1. Thomaz Frins era um pirata inglês, navegando com mais sete ingleses;

2. Frins liderava um patacho;

3. Foi da Inglaterra para Porto Belo, Panamá;

4. Pertencia a frota de navios pequenos e 900 homens, comandados por "Samoloy"; 5. "Andaram como piratas", saqueando as terras da coroa espanhola: Panamá, Callao, "barra da Ponta" $\left(5^{\circ}\right)$, Porto Santo $\left(9^{\circ}\right)$;

6. O barco de Frins separou-se da frota nas imediações de Callao;

7. Ficou "por seis meses" procurando o resto da frota;

8. Guerrearam em Porto Santo, no Pacífico, e "ficaram destruídos", sobrevivendo Frins e sete homens;

9. Necessitando de água e reparos, arribaram à Ilha de Santa Catarina; 10. Foram aprisionados por Francisco Dias Velho em 1687, que inventariou e confiscou a carga, e prendeu a tripulação.

O relato de Taques não é explícito sobre o destino do barco de Frins: informou estar avariado e tripulado por número insuficiente, navegando precariamente do Pacífico até Santa Catarina. Porém, é possível deduzir que afundou, pois aportou de arribada para reparos e abastecimento. A confirmação ${ }^{4}$ estará em outros documentos portugueses ou ingleses? Por que o barco de Frins não consta do inventário feito

(4) Ainda não investigamos os arquivos do Rio de Janeiro e Portugal. Não conseguimos encontrar registros da tripulação e da saída de Londres em 1683. O Nicholas era capitaneado por John Eaton, zarpando como barco comercial. O Cygnet, comandado por Charles Swan, saiu do Tâmisa com autorização do Primeiro Lorde do Almirantado, Duque de York (Burney 1891:164-165, 200; Lane 1998:144). Um terceiro comandante, "Capitão Townley", juntou-se à força após atravessar o Panamá em fevereiro/março de 1685 , e por diversas ocasiões formou dupla de ataque com Swan (Gerhard 2003:160-164). 
por Dias Velho durante a captura? O barco que chegou avariado teria afundado? Os testemunhos arqueológicos da Praia dos Ingleses servirão para confirmar definitivamente que foi o barco de Frins?

Os fragmentos da narrativa de Frins e sua cronologia coincidem com os registros da única frota pirata, a comandada por "Samoloy", ${ }^{5}$ por volta de 1687. Em junho de 1685, uma força de 960 homens comandada pelo inglês Edward Davis, reuniu-se para saquear colônias espanholas no Pacífico (Burney 1891:207). A esquadra pirata chegou a ter 10 barcos, a maioria tinha pouca tonelagem, dos quais sete foram capturados dos espanhóis. Todos os locais mencionados no relato de Pedro Taques foram assaltados ou visitados pelos piratas: Panamá, Callao, "barra da Ponta", situada em $5^{\circ} \mathrm{N}$, e "Porto Santo", posicionado em $9^{\circ}$ (trata-se de Santa María de la Parrilla, perto de Chimbote, Peru).

A parte inglesa da força surgiu em 1683-84, quando uma tripulação da Virgínia encontrou, na costa chilena e equatoriana, dois barcos que zarparam separados do Tâmisa. Em 1684, este grupo atacou e saqueou vários portos e barcos entre o Chile e El Salvador. A parte francesa associou-se posteriormente, em 1685. É com esse grupo que Frins atravessou o Panamá desde o Atlântico, com 80 ingleses liderados pelo “capitão Townley". É importante salientar que a força contava com várias nacionalidades, incluindo indígenas e escravos libertos pelos piratas. A aliança anglo-francesa acabou em poucos meses, após vários ataques bem sucedidos aos espanhóis, prosseguiram separados nas razias na costa entre 1685/86 e reuniram-se novamente em 1687 para atacar Guayaquil (Burney 1891:224). Dois cronistas dos piratas, William Dampier ([1697] 1702 p. ex.:199) e Raveneau de Lussan ([1689] 1856:334), ajudam a elucidar parte do caso de Frins: a força aumentou capturando barcos espanhóis, ${ }^{6}$ formando tripulações lideradas por quartermasters (contramestres), com postos chaves dominados por ingleses e franceses, além de outros europeus, entre os quais espanhóis renegados, mais escravos libertos e indígenas. O próprio Davis foi um quarter-master nomeado capitão geral após seu comandante falecer. Lussan dá o nome a seis dos dez comandantes. Seria Frins um dos quatro desconhecidos ou ele assumiu após seu líder morrer em combate ou doente?

A data da separação do barco de Frins do resto da frota é obscura no relato de Taques, mas é contextualizada nas fontes espanholas. Os piratas sofreram vários reveses entre junho de 1686 e junho de 1687, no Equador e no Peru. Taques escreveu que o desgarramento foi nas imediações de Callao, devido a combates navais ocorridos naquela área (maio/junho de 1687 cf. Zapata [1757] 2005:117), que não fecham com outra informação de Frins. Se ele procurou seus companheiros por seis meses, desde junho de 1687, não poderia ancorar na ilha de Santa Catarina naquele mesmo ano, pois a volta do Peru levava em média dois meses. As fontes espanholas mostram que os últimos combates na região entre Santa e Pisco, onde os piratas perderam vários combates e tiveram muitas baixas, ocorreram até junho de 1686 (Zapata [1757] 2005:279). Santa foi onde o grupo de Frins "ficou destruído", situada ao sul de Callao, relativamente próxima.

Junho de 1686 é coerente com uma informação de Lussan (1856:251), do encontro do grupo francês, em abril de 1687, nas imediações de Santa Helena, com um barco espanhol apresado pelo grupo de Edward Davis. O barco fora capturado na altura de Nazca, transportava vinho e milho, procurava pelos demais ingleses e era tripulado por oito ingleses que desembarcaram (isto é, atacaram) em "Sagua" (Tacna), Pisco
(5) Samoloy é uma evidente corruptela da forma original, feita na elaboração dos autos ou posteriormente. Só não sabemos quando, embora tenhamos candidatos para autoria do erro: 1) Lourenço Pereira, "Veneziano", intérprete de Frins nos autos; 2) escrivão dos autos; 3) Pedro Taques; 4) editor do livro de Taques. Acreditamos que foi a compreensão errônea, possivelmente, dos nomes Swan e Townley.
(6) Ainda não conseguimos acesso completo, mas estamos investigando a documentação espanhola das colônias do Pacífico para definir todas as localidades atacadas e identificar os tipos de assalto e os resultados dos piratas. Os espanhóis tomaram várias providências contra os piratas (Crahan 1971; Bradley 1979). Também procuramos pelos barcos apresados, onde foram construídos e quais suas cargas. 
e Arica. A ligação com Frins não é explícita, mas as coincidências com o relato de Taques são evidentes:

1) barco isolado tripulado por oito ingleses;

2) procurava pelos demais barcos

ingleses, dos quais perdera-se na costa

peruana;

3) barco era uma presa espanhola;

4) participou de ataques às cidades da costa peruana;

5) carregava uma carga de vinho (certamente em botijas de uma arroba);

6) pretendia voltar para o Mar do Norte (Atlântico), via Estreito de Magalhães.

O relato de Lussan é muito compatível com o relato de Pedro Taques, apesar de nenhum deles serem diretos e objetivos com relação a Thomas Frins. Ambos tratam de um barco com oito ingleses que se perderam do grupo principal na costa do Peru, após combaterem na costa, ao sul de Callao. As coincidências das demais informações também fortalecem o depoimento dos oito ingleses em duas ocasiões separadas, para ouvintes completamente distintos (piratas franceses e oficiais da justiça portuguesa), permitindo construir um relato com a mesma estrutura narrativa. E, como mostraremos abaixo, os depoimentos são coerentes com as evidências arqueológicas da Praia dos Ingleses.

Finalmente, mais duas coincidências com o inquérito de Frins: 1) Lussan (1856:340) informou que a força capturara um patacho espanhol em 13/05/1685 (seria o mesmo patacho descrito por Pedro Taques?); 2) o barco de Davis, Bachelor's Delight (Encanto dos Solteiros), teve quase o mesmo rumo de Frins na volta do Pacífico: parou para abastecer em Punta del Este no final de 1687 e, depois, costeou o Brasil (segundo outro cronista dos piratas, o cirurgião Lionel Wafer [1699] 1903:197). Parece que Davis passou ao largo de Santa Catarina um ou dois meses após a prisão de Frins. Testemunhas espanholas (Sotomayor [1688] $1901 \mathrm{a}, \mathrm{b}$ ), declararam que barcos ingleses aportaram em Maldonado, atual Punta del Este; e que um de 200 toneladas aportou de arribada em Buenos Aires antes de abril de 1688. Será que Frins também parou no rio da Prata?

\section{Alguns achados na Praia dos Ingleses e sua relação com o barco de Frins}

A escavação arqueológica revelou provas materiais originárias da costa pacífica, do noroeste da América do Sul e da América Central, que coincidem com as rotas dos piratas em questão. A mais evidente é um metate retangular $(52,28 \times 35,12 \mathrm{~cm})$, tetrápode, de rocha calcárea, empregado na América Central para moer vegetais, especialmente grãos (Fig. 2). Não é uma prova cabal de que o nosso barco esteve na América Central, pois o metate pode ter vindo a bordo através de outra embarcação ou localidade. Mas, está claro que os alimentos embarcados in natura precisavam ser processados para virar farinha, como o milho, alimento básico na América Central e costa noroeste da América do Sul. Seria evidência de indígenas na tripulação? Lembremos que as tripulações piratas contavam com indígenas e que saquearam milho em diversas localidades e barcos, como o do relato de Lussan. Consideramos que dificilmente um barco fora da América Central levaria um metate.

Um testemunho da presença do barco na costa noroeste da América do Sul é um fragmento cerâmico de vasilha indígena (Fig. 3). Trata-se de um artefato que possui características da Área Intermediária (Willey 1966:254), que no Pacífico abrange as costas do Panamá, Colômbia e Equador. Estava entre o lastro e, como não encontramos outros fragmentos deste tipo, não concluímos se pertencia a uma vasilha inteira ou se foi recolhido entre os seixos usados para lastrear a embarcação. Há outros fragmentos cerâmicos com características da Área Intermediária.

Outra evidência do Pacífico: fragmento fóssil da concha de loco (Concholepas concholepas Martyn), um molusco da família Muricidae apreciado como alimento, presente do sul do Peru ao sul do Chile (Fig. 4). É uma prova da viagem no Pacífico, mas também poderia ter chegado ao barco quando o lastro foi coletado em algum porto ou transferido de outra embarcação. Também achamos fragmentos de corais, ainda não identificados, que não apresentam características das espécies da costa brasileira e podem ser do Pacífico. 
Praia dos Ingleses 1: Arqueologia subaquática na Ilha de Santa Catarina, Brasil (2004/2005/2009).

Revista do Museu de Arqueologia e Etnologia, São Paulo, 19: 179-203, 2009.
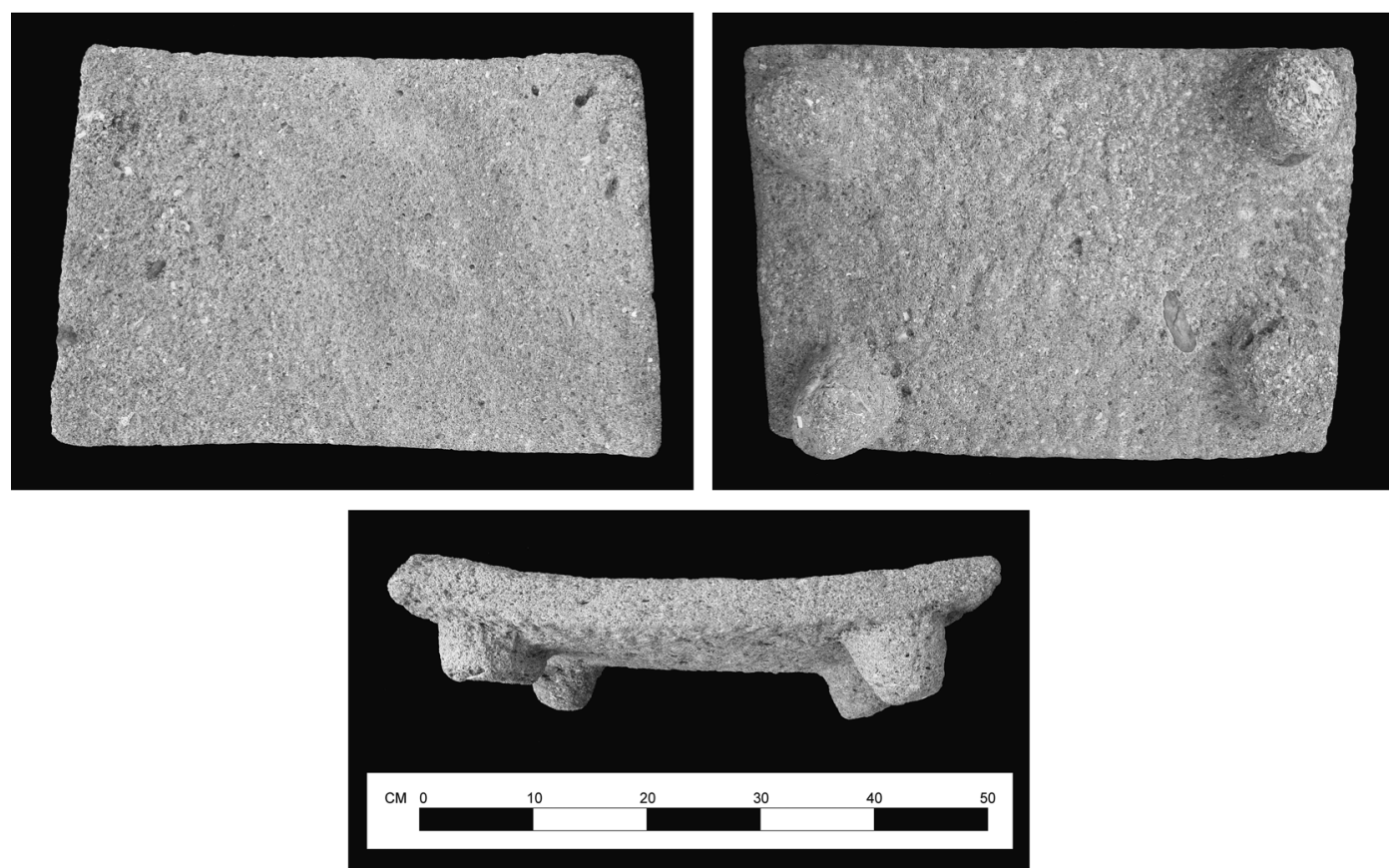

Fig. 2. Metate, plano de topo, base e vista lateral.

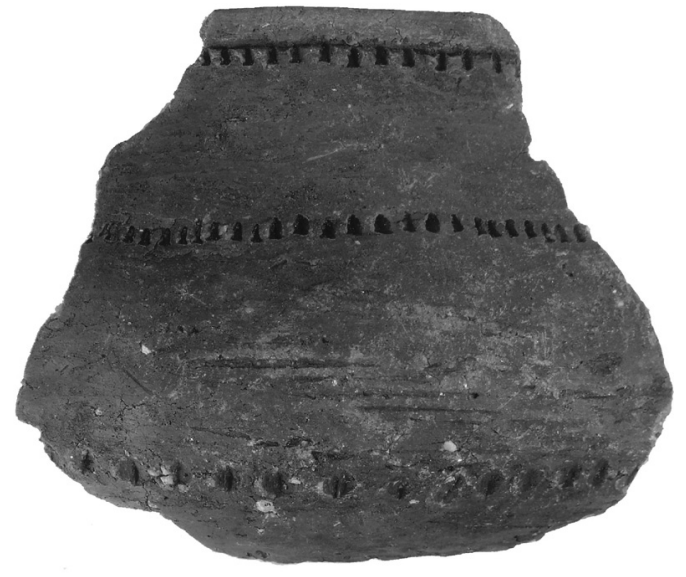

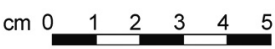

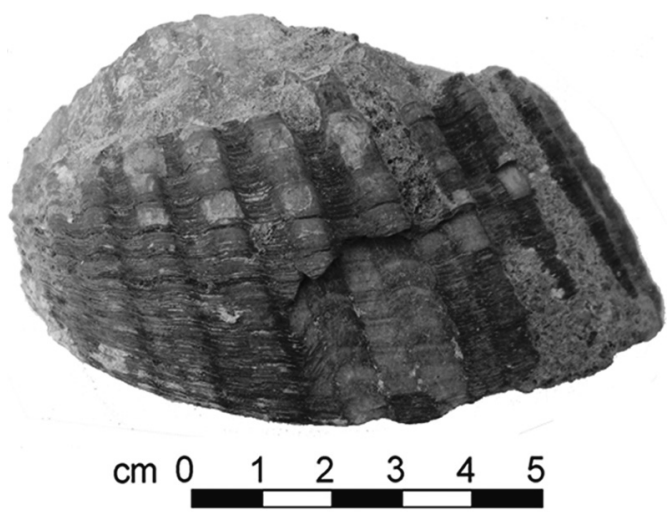

Fig. 4. Fragmento da concha de loco.

Fig. 3. Fragmento cerâmico típico da Área Intermediária. 
O lastro é outro dado arqueológico geralmente preciso para mapear o local de construção de um barco e de suas rotas, pois a região de origem das rochas pode ser determinada (Lamb 1988; Callahan, Miller, Craig 2001). Também serve para auxiliar a definir as dimensões de um barco a vela, correspondendo, em média, entre 10 e $15 \%$ do peso embarcado. Os cronistas da força pirata relatam diversas paradas para carenar os barcos, quando poderiam ter colocado ou retirado lastro. O estudo espacial e estratigráfico não foi concluído e estimamos ter escavado 20-30\% do lastro, que não está concentrado em uma pilha, mas está depositado em diferentes feições sobre solo arenoso. A principal feição forma uma pilha, concentrada sobre a extensão do eixo da quilha. As demais feições compõem o campo de destroços, irregularmente concentradas fora da área do casco, possivelmente dispersas no colapso do naufrágio e no período pós-deposicional, como na forte ressaca de 1838 que mencionamos acima (Fig. 10). A pilha de lastro apresenta espessura variável, no máximo 1,3 m nas quadrículas 2, 3, 11, 12, com médias de 50-60 cm quando se afasta da área mais espessa. A composição? predominante do lastro são as rochas ígneas, especialmente seixos de basalto variando entre 60-0,2 cm. Também compõem o lastro, em pouca quantidade, rochas de outros tipos e concreções de alvenaria com tamanhos variados, que são distintas das concreções pós-deposicionais. As camadas mais espessas apresentam uma mistura de seixos grandes/médios envolvidos por seixos pequenos, provavelmente distribuídos de forma semelhante como estavam no porão do barco. Apenas nas quadrículas 1, 2, 3 e 4 encontramos seixos maiores sobre a massa principal, não ocorrendo um padrão de distribuição do tipo "inverso" (Garrison et al. 1989:7-1), com predomínio de seixos grandes sobre os pequenos.

(7) Existem diversos bancos de dados que poderão auxiliar o mapeamento do lastro (p. ex.: PETDB Petrological Database; SESAR System for Earth Samples Registration; Marine Geoscience Data System). Recolhemos o lastro para criar um diorama no futuro museu, reproduzindo sua distribuição no registro arqueológico.
Nossa conclusão preliminar sobre essa área da escavação é que o barco bateu violentamente no fundo, primeiro abrindo o tabuado do costado de popa e espalhando parte do lastro e da carga fora do casco. Depois tombou para boreste, com o lastro e parte da carga derramando-se e misturando-se no mesmo sentido. Recolhemos mais de 26 toneladas de seixos e as prospecções e pontos de erosão indicam que resta muito lastro nas áreas não escavadas do sítio arqueológico. Se o barco é um patacho, poderia deslocar mais de 200 ton, carregando mais de 35 ton de lastro. $\mathrm{O}$ leme com $6,7 \mathrm{~m}$ de altura permite estimar que seja um patacho grande, com mais de $22 \mathrm{~m}$ de comprimento.

Outro elemento mineral encontrado em diversos fragmentos de botijas foi o alcatrão. Os barcos poderiam ser tratados com este elemento na sua construção e poderiam levar estoque para reparos. O relato de Dampier (1702:134), que os habitantes da Ponta Santa Helena, Equador, guardavam alcatrão mineral em botijas para usar em barcos, é uma outra importante coincidência com os achados na Praia dos Ingleses. Embora Dampier não declare que os piratas pegaram alcatrão, é provável que eles o estocaram nas botijas. Os cronistas espanhóis relataram sua existência em Santa Helena desde o princípio da conquista do Peru, e Pedro Cieza de León escreveu em 1553 que era o "alcatrão tão perfeito, que poderiam calafetar com ele a todos os navios que quiserem". A área integra a bacia petrolífera Progreso, do bloco Santa Helena (Hingley 2004).

As madeiras constituem outras evidências que poderão ajudar a identificar a região de origem do barco. O carvalho vermelho (Quercus robur L.) da quilha é encontrado na Europa e América do Norte. A análise de outras madeiras será realizada, para definir espécies e proveniência. A posição dos cravos no tabuado da forração externa do costado é típica da técnica de construção espanhola, distinta da inglesa (Aispuru 2003:26-28).

Encontramos mais de 11 mil fragmentos de cerâmicas, compostos basicamente por botijas de una arroba do tipo Forma 1 (James 1988), usadas para transportar e armazenar vinho, azeite, água, grãos etc. Localizamos 10 botijas inteiras e cerca 
de 270 gargalos. Já restauramos oito botijas (Fig. 5), havendo mais nas áreas não escavadas, conforme prospecções e locais de erosão. Elas eram produzidas artesanalmente em grande escala, com forma padronizada e não eram exatamente iguais (Avery 1997), contendo entre 16 e 22 litros e pesando entre 8 e 11 quilos. A análise visual da pasta, da espessura das paredes e do tratamento de superfície, indica que as vasilhas não são de um único oleiro, nem de uma única jazida. Tal diversidade coincide com as informações de que a força pirata saqueou botijas de vinho e água em diversas localidades e barcos nas costas centro e sul americanas (Burney 1891). As botijas podem ser da Espanha ou das haciendas peruanas, a exemplo das produzidas em Moquegua (Rice 1996), e a composição da pasta poderá auxiliar na localização de onde as vasilhas foram produzidas. O relato de Lussan visto acima, informa que o barco capturado pelos oito ingleses trazia uma carga de vinho, certamente acondicionada em botijas. As botijas e fragmentos da etapa 2004/2005 já estão dessalinizadas, em processo de análise e há várias em reconstrução. Estamos analisando os gargalos e reconstruindo graficamente a forma das botijas (Fig. 6):

Uma escala de Gunther para navegação, com marca e ano de fabricação pirografados, é outra coincidencia relevante e que ajuda na datação relativa da embarcação (Fig. 7). O ano é
1683, justamente quando os ingleses saíram da Virgínia e do Tamisa, e o nome da marca é tipicamente inglês. Provavelmente, a escala foi levada para o barco espanhol com os instrumentos de navegação dos quarter-masters. Em destaque, ampliamos o que parece ser o ano da elaboração e a marca do fabricante (ou do proprietário?), que não estão totalmente legíveis.

\section{O ambiente e a formação do registro arqueológico}

A posição da Praia dos Ingleses 1 permite economia logística, mas o ambiente e a geomorfologia influenciam nos aspectos pósdeposicionais, complicando a conservação e oferecem risco à preservação do sítio arqueológico. É um belo recanto à beira-mar, submetido aos impactos antrópicos causados por milhares de banhistas, embarcações e por ser uma centenária área de pesca artesanal de arrasto. $\mathrm{O}$ ambiente também afeta o sítio, tratando-se do local mais dinâmico da zona costeira: a praia arenosa (Shepard 1973). A ação constante das ondas e marés cria processos de erosão ou acresção sedimentar, podendo transformar o perfil do ambiente da praia em poucas horas (Mendes 1992). O balanço sedimentar do local também é influenciado pelos ventos do quadrante sul, que
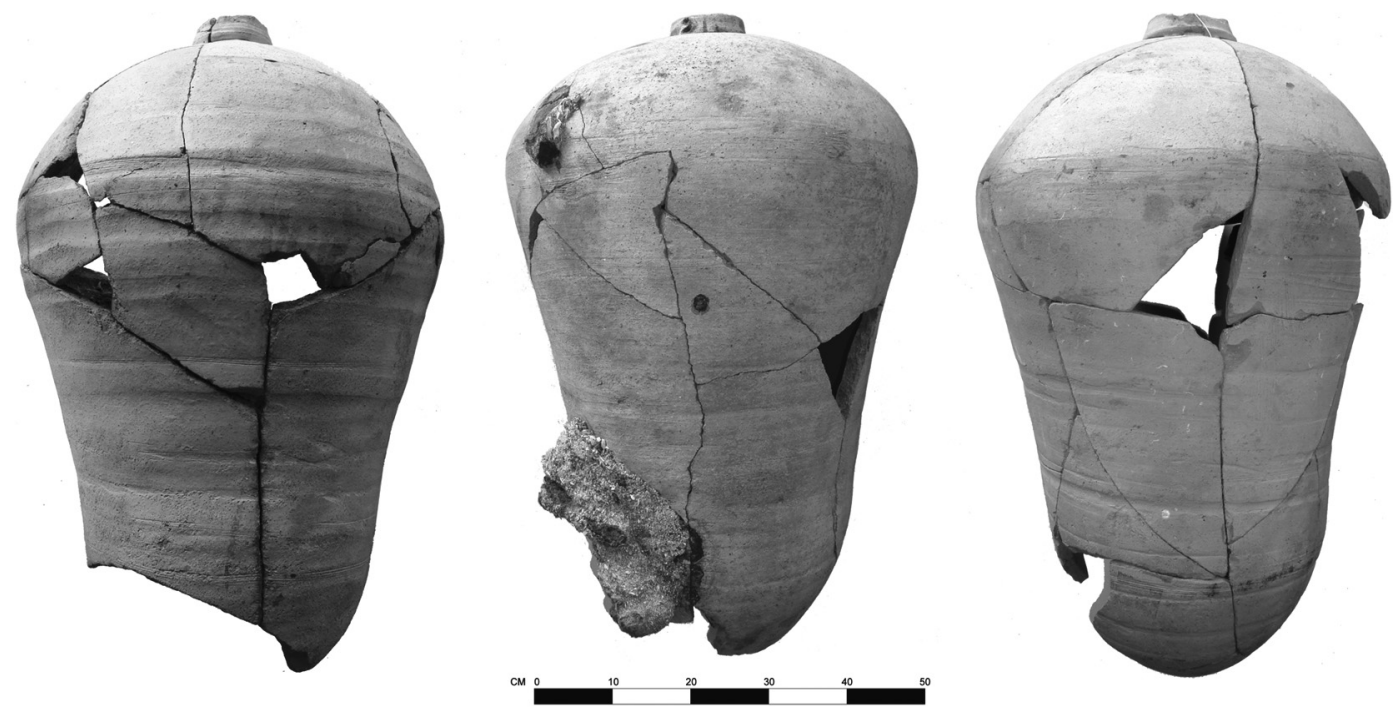

Fig. 5. Exemplares restaurados de botija de uma arroba. 

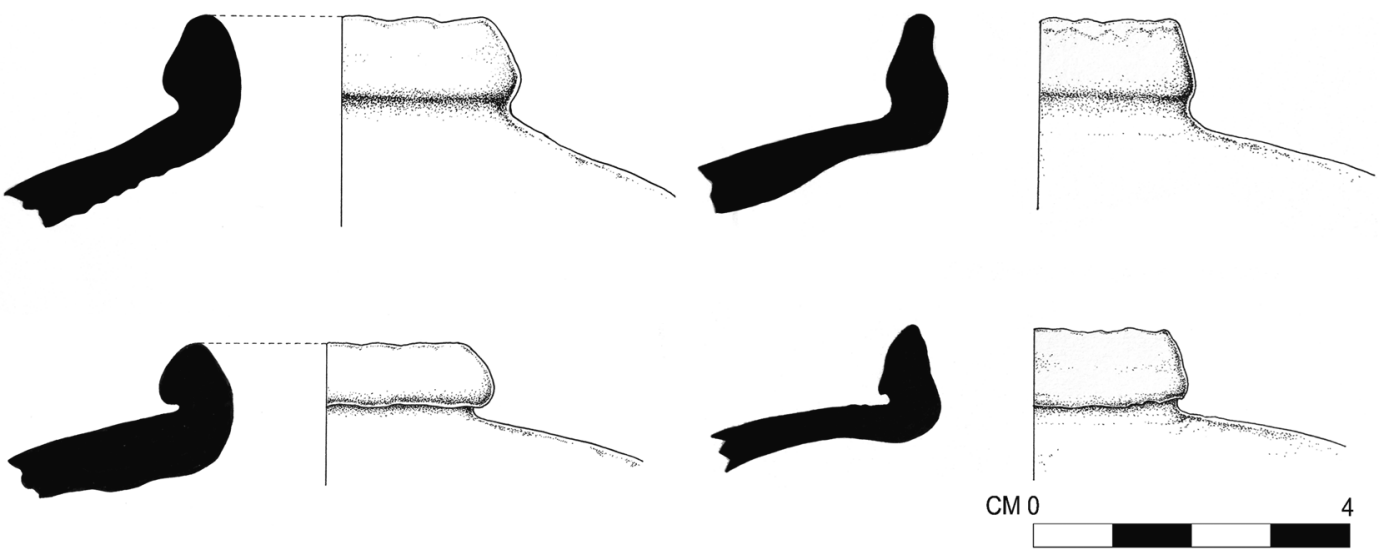

Fig. 6. Exemplares de perfil da borda dos gargalos das botijas de uma arroba.

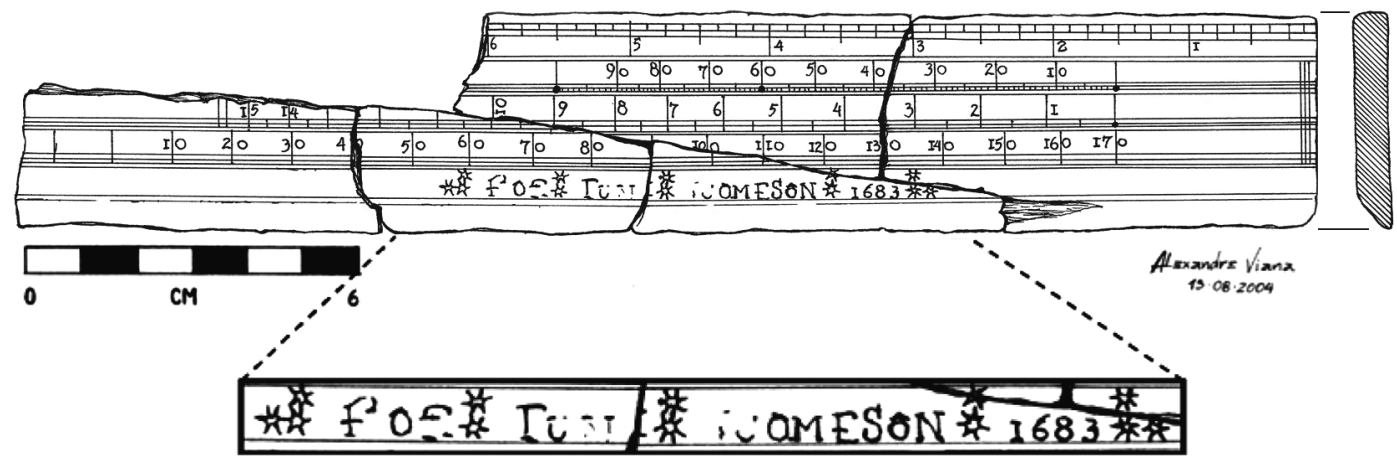

Fig. 7. Escala de Gunther.

alimentam a enseada com areias das dunas das Aranhas (Faraco 2002). O resultado, dependendo da ação individual ou conjunta desses fatores, altera o pacote sedimentar sobre o sítio arqueológico, deixando-o mais ou menos espesso sazonalmente (Marino 2006). Sofremos três ressacas durante a escavação, verificando a variação do pacote em poucas horas/dias de centímetros até um metro. As mais fortes ocorreram entre 22-25/10/2004 e 2326/04/2009 (Fig. 8). Lembramos a grande ressaca de 1838 que citamos, considerada a maior já registrada na região, provocando uma erosão que perturbou de forma significativa o sítio arqueológico e que deve ter alterado o contexto e contribuído na perda de quantidade considerável de evidências.

A circulação das águas também determina a dinâmica morfológica da enseada dos Ingleses. $\mathrm{O}$ sentido pode ser medido por granulometria, grau de seleção dos sedimentos e pela presença de matéria orgânica e carbonato biodetrítico. Além de medir toda a enseada, Marino (2006) verificou que no sítio arqueológico há areia fina bem selecionada, com pouca matéria orgânica $(0,2 \%)$ e médio teor de carbonato biodetrítico (6\%). Esses dados, somados a mapas batimétricos, análise das marés e ventos, permitiram concluir que o sítio arqueológico está em um ponto sensível de erosão/acresção sedimentar. Segundo Faraco (2002), as maiores variações do perfil da enseada devem-se às ondas de leste e a ventos fortes do quadrante norte. As fases de estabilidade/acresção foram associadas às ondulações com menor energia de sul/sudeste, cujos ventos movimentam material das dunas. As fases acrescivas são benéficas e espessam o pacote sedimentar, protegendo o sítio arqueológico. As fases erosivas afinam o pacote, expondo as evidências materiais ao impacto hidrodinâmico, biológico, físico-químico e antrópico. Ambas as fases impactam, alterando a turbidez da água e 

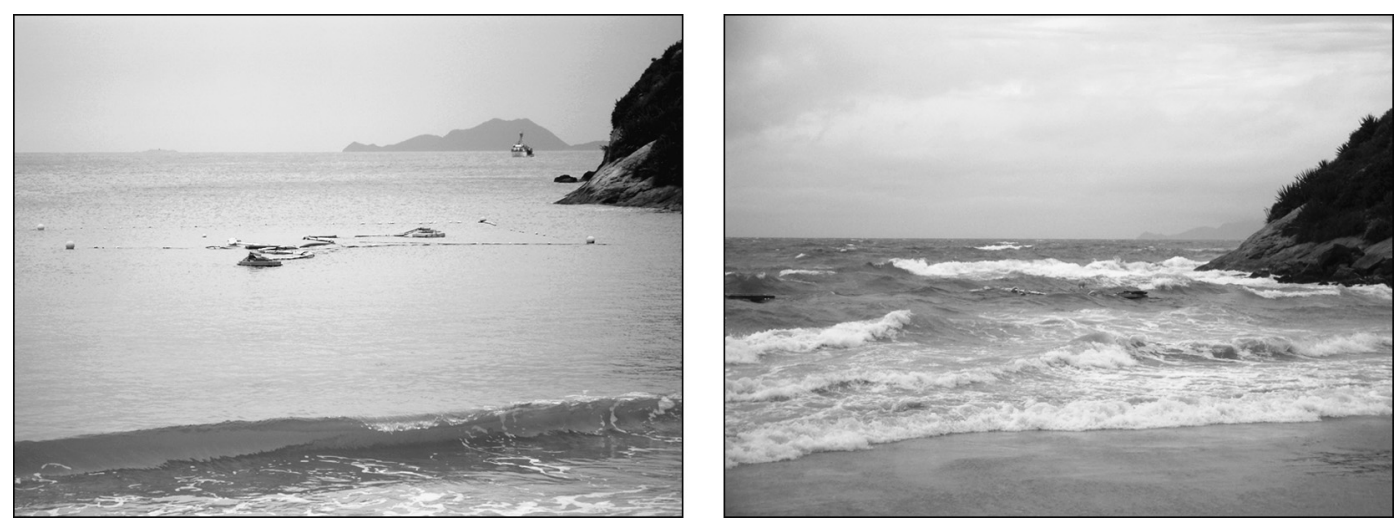

Fig. 8. Condições extremas do mar na área de escavação: da calmaria à ressaca.

introduzindo sedimentos, algas e lixo nos espaços escavados. A visibilidade máxima pode chegar a $6-8 \mathrm{~m}$, mas as médias ficam entre $60-80 \mathrm{~cm}$, e muitas vezes é menor chegando a visibilidade zero, dificultando ou impedindo a escavação e os registros com foto e desenho.

A configuração do sítio arqueológico resulta de processos naturais e culturais que podem intervir, mover, modificar e dissolver os artefatos (Muckelroy 1978:169). O mais comum na fase erosiva é a movimentação dos artefatos pelas ondas e marés de leste/norte, arrasto de redes e âncoras, espalhando ou quebrando os mais leves como madeiras e vasilhas cerâmicas. A instalação de poitas intervém quando são colocadas diretamente no sítio arqueológico. A dissolução dos metais ocorre pela corrosão e a degradação deve-se à fauna que come as madeiras e outros materiais orgânicos, que ficam estruturalmente enfraquecidos e são destruídos pelas correntezas. Todos esses fatores são acentuados por pessoas que circulam à beira da praia ou mergulham na área do sítio, alterando ou removendo evidências materiais expostas na fase erosiva.

Os restos da embarcação estão enterrados e ligeiramente inclinados no sentido longitudinal acompanhando o perfil do leito marinho, com a área da popa no local mais elevado e sensível aos fatores erosivos. Não há presença de mound e o terreno apresenta declive suave e aplanado (Fig. 9). Nas fases erosivas prolongadas surgem evidências no campo de destroços na direção da praia e do costão, na área mais rasa. $O$ pacote de sedimentos estéreis sobre a camada arqueo- lógica alcançou até o presente uma espessura máxima de $2,5 \mathrm{~m}$.

Nos $220 \mathrm{~m}^{2}$ escavados até maio de 2009, encontramos evidências que permitem uma hipótese preliminar sobre as causas do naufrágio e o processo deposicional: 1) encalhe em condição de ressaca e ventos do setor noroeste; 2 ) ruptura do casco após impacto no solo; 3) partes do lastro e da carga foram para fora do barco; 4) finalmente, casco adernou para boreste. A parte final da quilha apresenta dois cravos com 1,7 e 1,5 m de comprimento, $14 \mathrm{~cm}$ de diâmetro, retorcidos para boreste, uma prova do desabamento da estrutura de popa logo em seguida do impacto no solo. Essa parte da quilha, de fato os últimos 3,58 $\mathrm{m}$ de comprimento, apresenta marcas do impacto, pois ela está quebrada (a peça original deveria ter $\pm 9 \mathrm{~m}$ e integrava a parte final de um conjunto de 3 peças, característicos da quilha espanhola da segunda metade do século XVII, cf. Aispuru 2003). A maior parte do trabalho ocorreu na área da popa e no campo de destroços à ré e a boreste dos restos do casco. A quilha está alinhada para noroeste, justamente no local do registro arqueológico mais sujeito à exposição nas fases erosivas. A superfície da quilha apresenta degradação das vezes que ficou sem cobertura sedimentar, causada pela fauna e as peças que estavam firmemente afixadas nela, como a curva coral, a sobrequilha, o cadaste de popa e a falsa-quilha, ainda não foram localizadas (provavelmente foram degradadas).

Não tocamos ainda a área central e a proa, que estão enterradas (esperamos fazer um mapa 


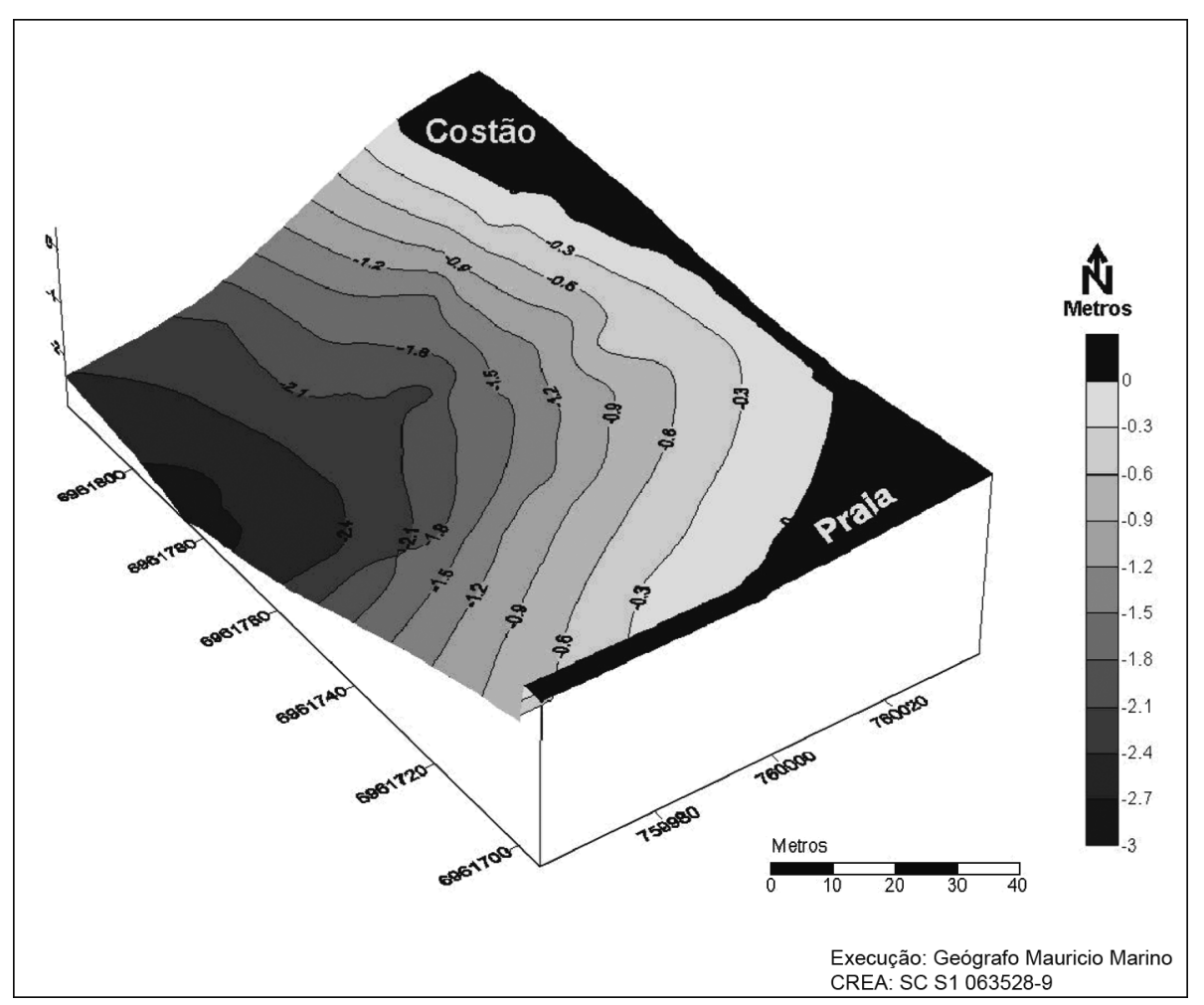

Fig. 9. Modelo Digital do Terreno representando a batimetria da área do sítio arqueológico em $13 / 4 / 2004$.

geofísico para determinar a posição exata destas partes). Outras madeiras, do costado, apresentam as extremidades próximas da popa com marcas de que também ficaram sem cobertura sedimentar. A cerca de $80 \mathrm{~cm}$ da quilha encontramos o leme, intacto, fato que indica o limite da área onde o pacote sedimentar deixava de afinar a ponto de expor o registro arqueológico. A posição da quilha e das madeiras do costado encontradas até agora indicam que o barco adernou para boreste após naufragar. As concreções do tabuado do costado indicam que o cavername daquela parte ficou exposto ao ambiente e foi destruído pela ação ambiental e pela fauna. Não localizamos, além da quilha, nenhuma parte estrutural do casco. As madeiras do costado estavam entre o lastro, e pertencem à área de transição da popa para o terço central do casco (o desenho da estrutura está em andamento e, futuramente, publicaremos sua posição em relação ao solo e ao lastro). $O$ desenho e o fotomosaico da escavação mostram o topo do contexto arqueológico (Figs. 10 e 11). A Figura 12 representa as pranchas do costado de boreste, marcadas pelas concreções dos cravos, que foram removidas do sítio e se encontram em processo de dessalinização. A Figura 13 mostra o leme e a quilha na posição que ocupariam no casco, atualmente em processo dessalinização, prestes a iniciar tratamento químico.

\section{A escavação}

A escavação subaquática, conforme Adams (2002:192): "é o desmantelamento controlado dos depósitos submersos, para revelar superfícies, estruturas, objetos e materiais relativos à existência do passado humano (...). Tal como na terra, os sítios arqueológicos subaquáticos não podem ser não-escavados; conseqüentemente o processo é inerentemente destrutivo e apenas pode ser mitigado através de registro e publicação". Como na terra, realizamos a prospecção, escavação e remoção, intermediadas pelo registro detalhado e, 
quando necessário, pela conservação in situ e no laboratório de materiais frágeis, procurando seguir sempre os mais elevados padrões técnicos dentro da perspectiva de que a escavação não é um fim em si mesmo (Bass 1980:143; Dean 1988; Marsden 1994; Green 2004:236).
A escavação teve duas etapas, com mais de 1.200 mergulhos concluídos sem nenhum incidente para a equipe: 1) março de 2004/ fevereiro de 2005; 2) fevereiro/maio de 2009. Ambas foram interrompidas pela pesca da tainha (29/04-26/07/2004; 15/05-31/07/

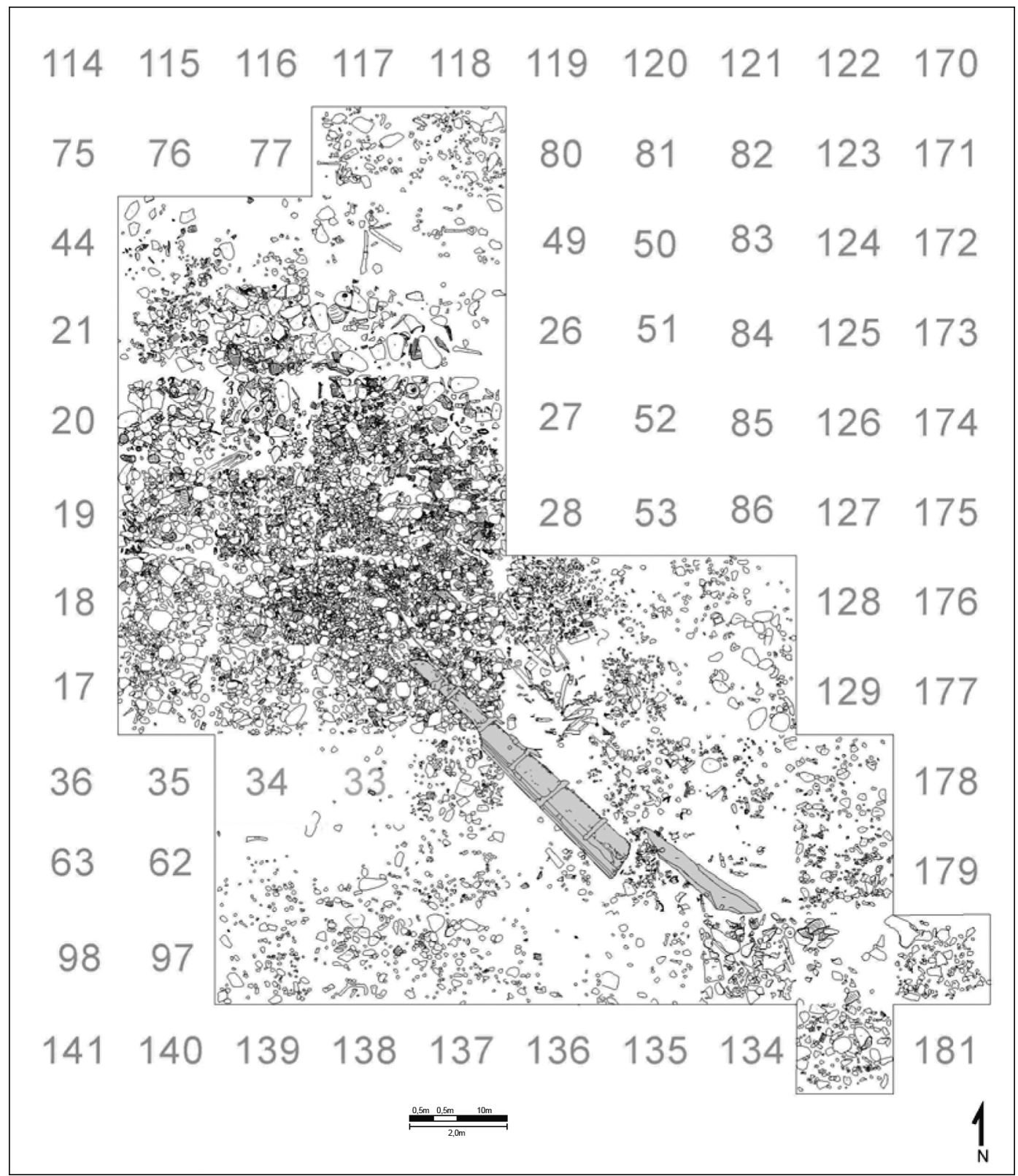

Fig 10. Sítio Praia dos Ingleses 1.

Área total de Escavação: $220 \mathrm{~m}^{2}$

Temporadas: 2004 - 2005 - 2009 


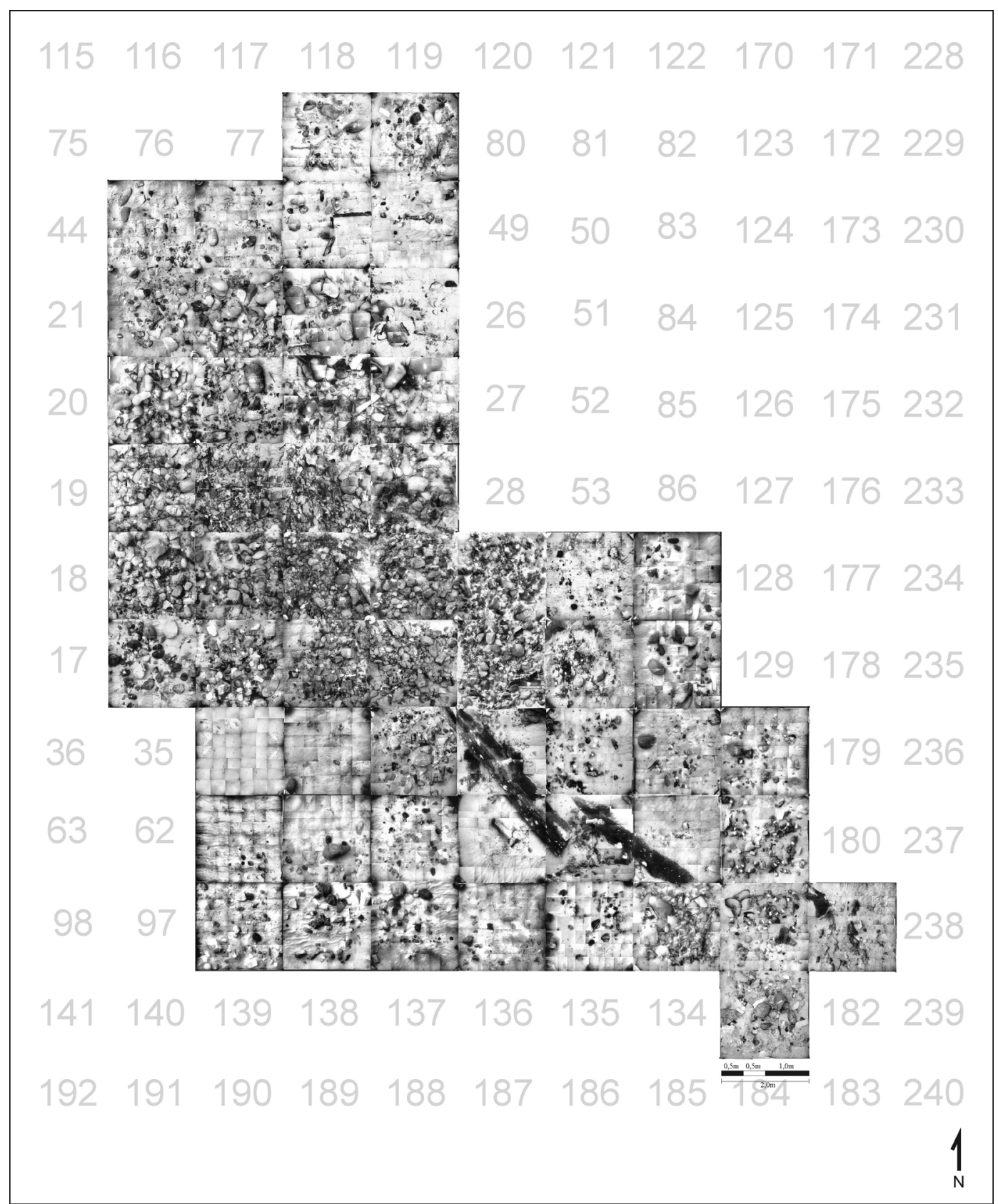

Fig 11. Sítio Praia dos Ingleses 1.

Área total de Escavação: $220 \mathrm{~m}^{2}$

Temporadas: 2004 - 2005 - 2009

2009). Foram seis dias por semana, com dois ou quatro mergulhadores em ação (mais o apoio fora da água), totalizando 173 dias na etapa 1, com 1.172 horas/equipe (média de
6,7 horas/dia/equipe). Na etapa 2 foram 82 dias, com 827.06 horas/equipe (média de 10,22 horas/dia/equipe). As condições climáticas e de visibilidade subaquática 


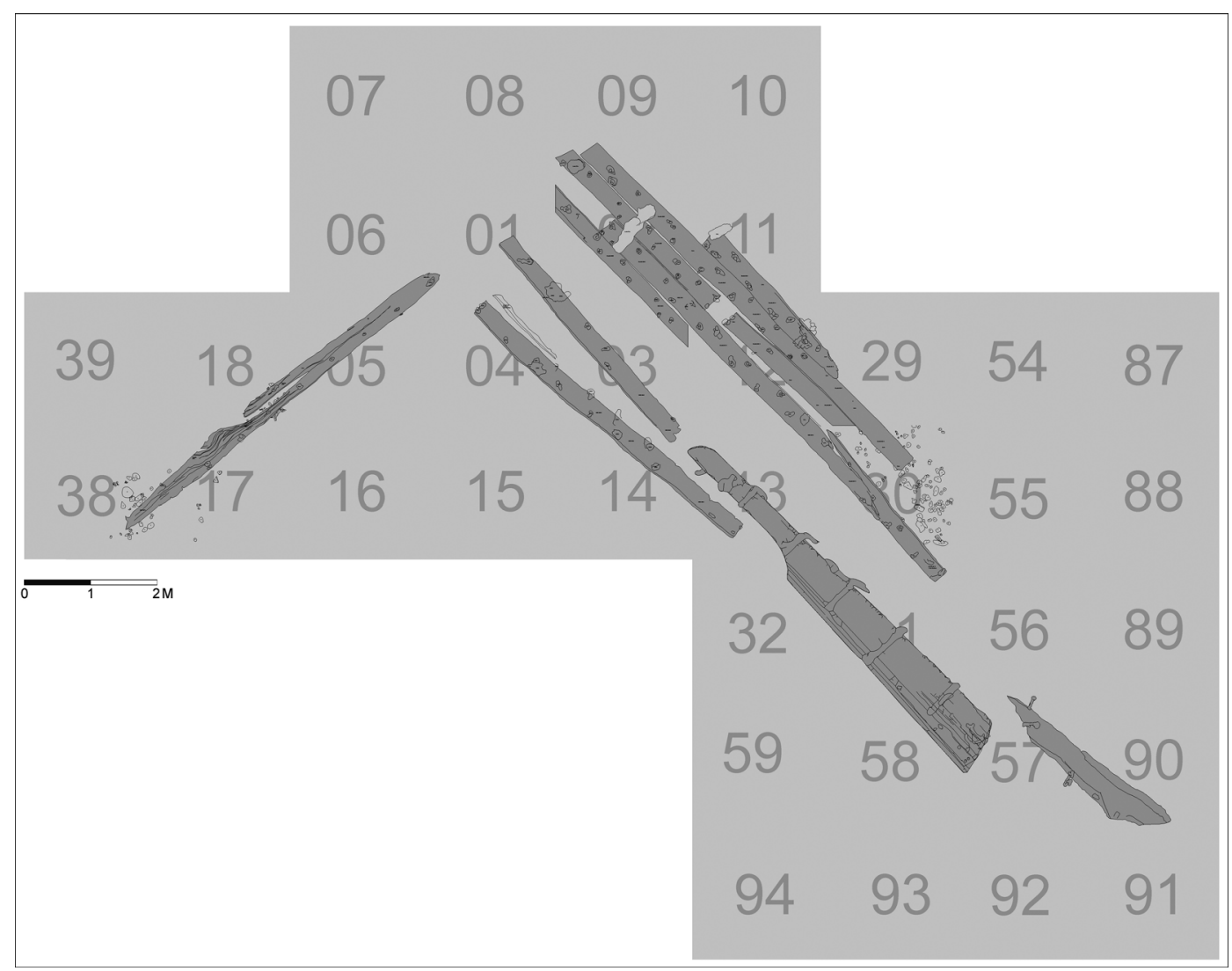

Fig. 12. Tabuado do costado de boreste, leme e fragmento da quilha.

favoreceram a segunda etapa, possibilitando mais dias e horas de trabalho subaquático. Realizamos, paralelamente, o trabalhado de laboratório, a pesquisa bibliográfica, a consulta às bibliotecas virtuais e fomos aos arquivos públicos de São Paulo e Santa Catarina. A escavação parou em abril de 2005 e reiniciou em fevereiro de 2009, mas a conservação não foi interrompida, sendo realizada na UNIVALI. A pesquisa histórica prosseguiu entre 2005 e 2008.

Para fins de registro dividimos a área da escavação em quadrículas de $4 \mathrm{~m}^{2}$,georreferenciadas com pontos de controle subaquáticos e terrestres. Os pontos terrestres partiram de um marco geodésico. Foi usado um DGPS (Ashtec Tecnology) com bases fixa e móvel com precisão de $5 \mathrm{~mm}$ e uma estação total (Leica Geosystems). A marcação das coordenadas foi realizada com o deslocamento do prisma no topo de uma haste apoiada diretamente nos pontos de controle das quadrículas. As marcações foram transferidas para o programa ArcView 8.3, convertidos em arquivos shapefile e processados para permitir a geração de arquivos vetoriais, para integrar os desenhos e fotos usados para construir o mapa geral da escavação e das estruturas em 3D (Marino 2006:56).

As quadrículas são balizadas por quadrados com $2 \mathrm{~m}$ de lado, de barras de ferro galvanizado afixadas em uma base do mesmo material, que se ajustam à superfície do terreno (Fig. 14). Essa técnica substituiu com vantagem as estacas e cordames, não perturba a camada arqueológica e permite a rigorosa orientação espacial. Suas bases são constantemente enterradas pelos sedimentos, estando sempre firmes em seus lugares. A partir do datum zero, foram justapostas várias quadrículas que podem ser 


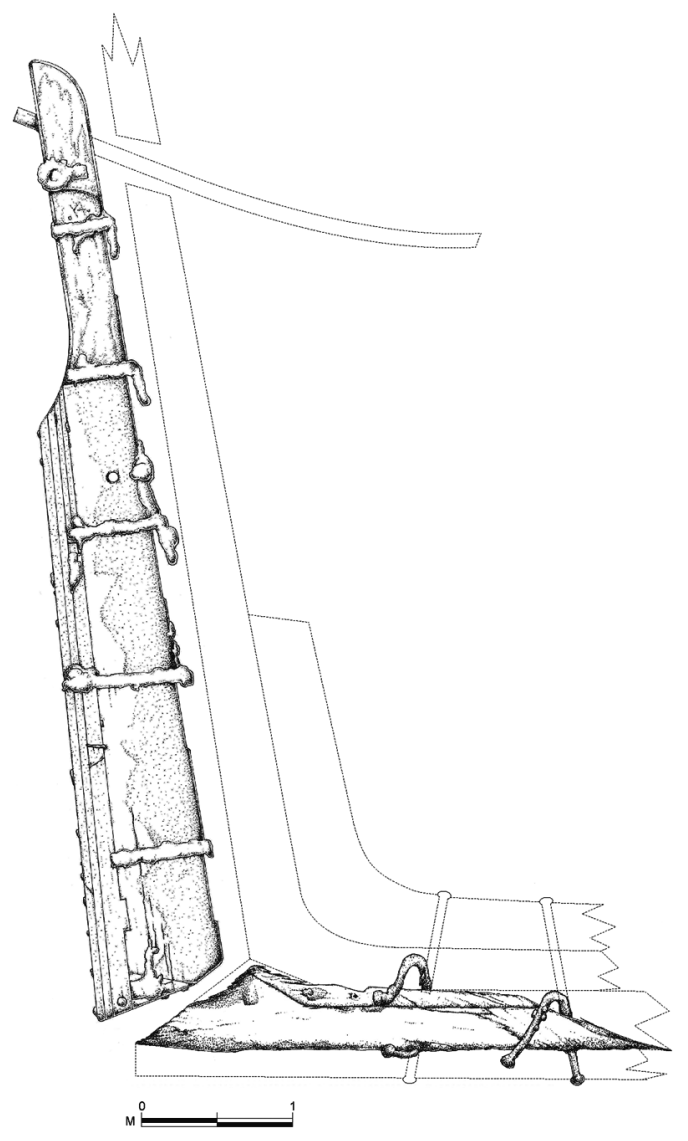

Fig. 13. Leme e quilha em suas posições no casco. Os cravos da quilha estão torcidos para boreste.

movidas em todas as direções conforme avança a escavação, sem perder o alinhamento e as coordenadas geográficas. Quando o trabalho é interrompido algumas quadrículas ficam enterradas para retomar a escavação sem perder a posição da área.

Para o registro com desenho e fotografia é acoplado nas quadrículas metálicas um gabarito de aço nivelado na horizontal, marcado em intervalos de $10 \mathrm{~cm}$, servindo como régua para mensurações, balizamento e orientação da escavação e do registro. Após a conclusão do registro e da remoção dos artefatos, é aberta nova área de escavação e o processo repetido, em espaços previamente numerados e definidos em plano cartesiano, dispostos no eixo $\mathrm{X} / \mathrm{Y}$, permitindo a orientação geométrica e um registro que reproduza o contexto arqueológico em 3D. As peculiaridades locais obrigaram a adaptar os métodos de registro (Green 2004). A luta travada entre a imprecisão meteorológica, o cronograma e a conservação, nos levou a abrir pequenas unidades de escavação $\left(4 \mathrm{~m}^{2}\right.$ por vez) e eliminar o uso constante de trenas e réguas, aplicando outras técnicas de registro que representem com fidelidade e detalhe o contexto escavado, para análise e publicação. Foram três técnicas de registro: catalogação, desenho e fotomosaico (Fig. 15). Os objetos são etiquetados e desenhados in loco (escala 1:1) em pranchas de acrílico de $1 \mathrm{~m}^{2}$. No laboratório os desenhos são transferidos para papel vegetal de $1 \mathrm{~m}^{2}$ (escala 1:1) e, a seguir, copiados na mesa digitalizadora e arquivados eletronicamente em CORELDRAW para compor o mapa da escavação (escala 1:1). A turbidez e a pouca profundidade obrigaram a posicionar a câmara fotográfica a uma distância média de 1,2 $\mathrm{m}$ do solo, com 42 fotos por $4 \mathrm{~m}^{2}$.
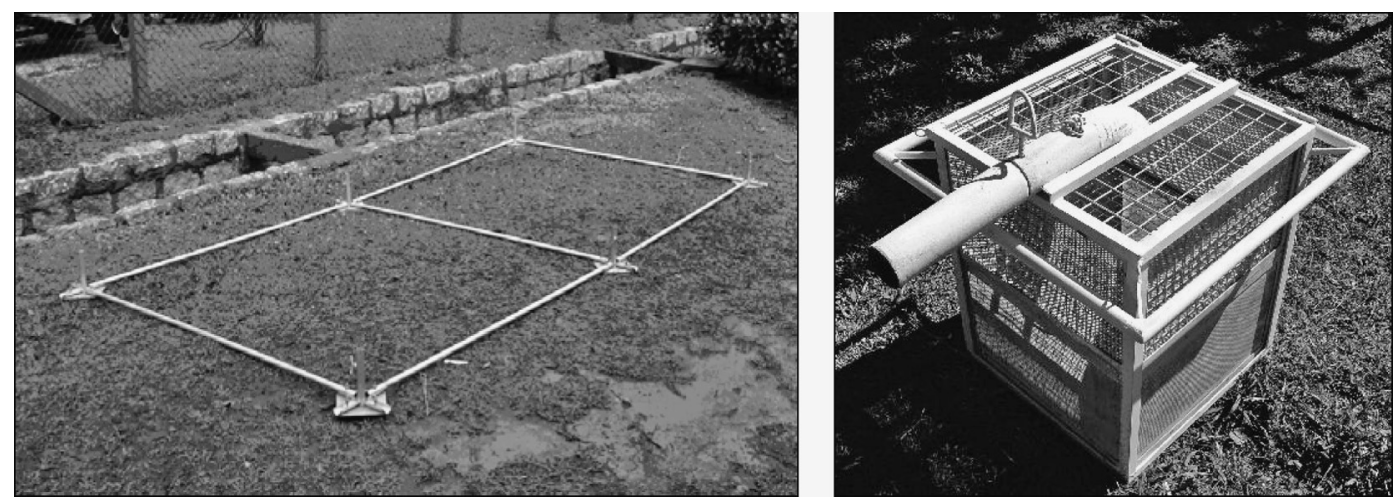

Fig. 14. Quadrículas metálicas e peneira. 
As fotos são digitalizadas e tratadas inicialmente com ADOBE PHOTOSHOP (cor, contraste, brilho, dessaturação e equalização de curvas), arquivadas com alta resolução; a seguir, com o CORELDRAW, é montado o fotomosaico de uma quadrícula com resolução variável entre 300 a $600 \mathrm{dpi}$. O fotomosaico geral de toda a escavação é mais fácil de trabalhar com ADOBE PHOTOSHOP (partimos do modelo de Martin e Martin, 2002). A elevada turbidez limitou, geralmente impediu o registro panorâmico do contexto arqueológico e do processo de escavação, restringindo a visibilidade a pouco mais de uma quadrícula e seu entorno imediato. Há pequenas diferenças entre desenho e foto, mas conseguimos um elevado nível de precisão com o desenho, considerando as dificuldades visuais impostas pela turbidez da água. Procuramos realizar esses registros sempre próximos do meio dia por causa da iluminação natural, com o sol no zênite (eventualmente, a condição da água atrasou o horário).

Detalhe do registro, comparando o desenho com o fotomosaico de uma quadrícula $\operatorname{com} 2 \mathrm{~m}$ de lado (Fig. 16):

Antes de cavar, as quadrículas metálicas foram instaladas sobre a camada estéril, para balizar o trabalho. O solo estéril é rebaixado em linhas paralelas para acomodar gradativamente um conjunto de quadrículas até a altura anterior ao início do registro arqueológico, cuja topografia é irregular devido às diferenças volumétricas do conteúdo. A forma da área da nossa escavação é côncava, cercada de barrancos de altura variável chegando ao máximo de $2,5 \mathrm{~m}$ abaixo do nível do solo. Como o comportamento das marés e correntezas foi normalmente acrescivo, tendendo a assorear a escavação, adotamos uma estratégia de contenção distanciando os barrancos nas principais zonas de acréscimo, removendo periodicamente o assoreamento (Fig. 17). Com a força do mar, não conseguimos instalar barreiras ao redor da escavação. As técnicas empregadas variaram conforme a composição da camada.

Os principais instrumentos foram a mão, para abanar o sedimento e a "poeira" (Fig. 18); e o air lift, o equipamento padrão da arqueologia subaquática desde os anos 1950. O desenho contemporâneo e o conceito de manuseio cuidadoso foram estabelecidos em 1960-61 por George Bass (1971:138), que o considerou como a "pá" do arqueólogo subaquático. Trata-se de um cano rígido onde passa ar comprimido introduzido na extremidade junto ao solo, para extrair sedimento e transportá-lo até a peneira fora da área da escavação (Adams 2002; Green 2004:252-256). O poder de sucção depende da relação entre o diâmetro do cano $(6-16 \mathrm{~cm}$ em média), profundidade e volume de ar fornecido pelo compressor. Quanto mais espessa a coluna de água sobre o local de trabalho, maior a capacidade de sugar metros cúbicos de sedimentos por hora trabalhada. Embora seja um aparelho indicado para profundidades a partir de dois metros, nós empregamos em lâmina de água de até um metro devido à maré baixa e ao espessamento do pacote sedimentar, quando a capacidade de sugar por hora fica tremendamente reduzida. Sua função primária, com canos de
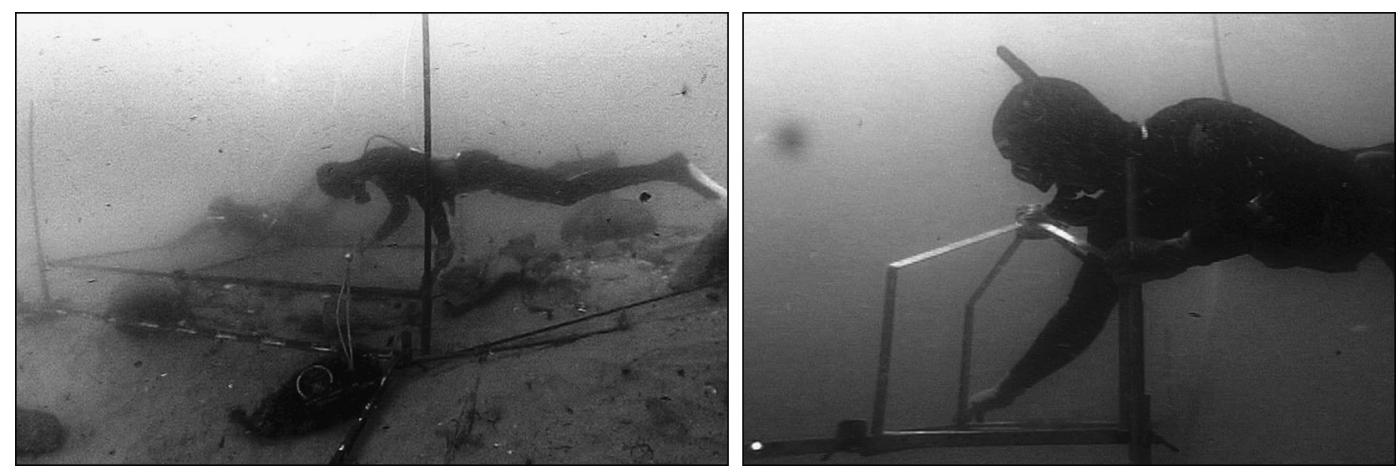

Fig. 15. À esquerda registro com desenho na placa de acrílico; à direita, fotografia. 


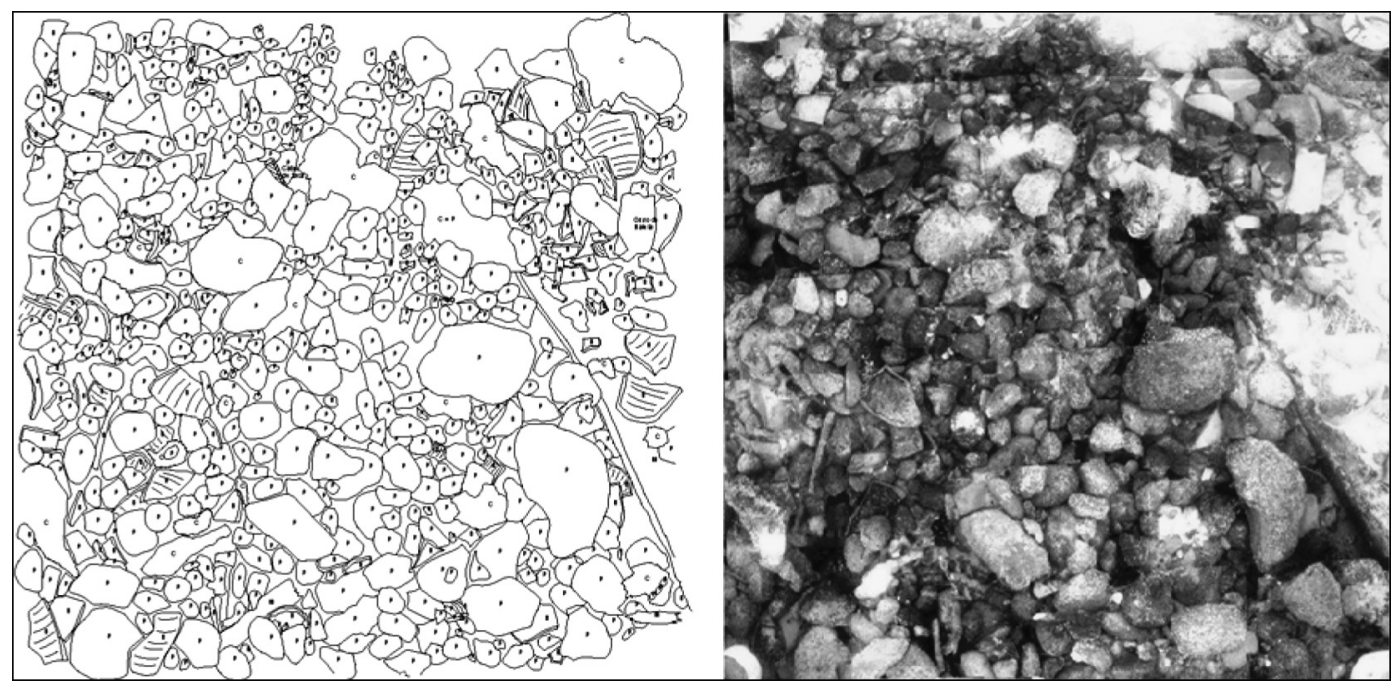

Fig. 16. Desenho e fotomosaico da quadrícula 03.

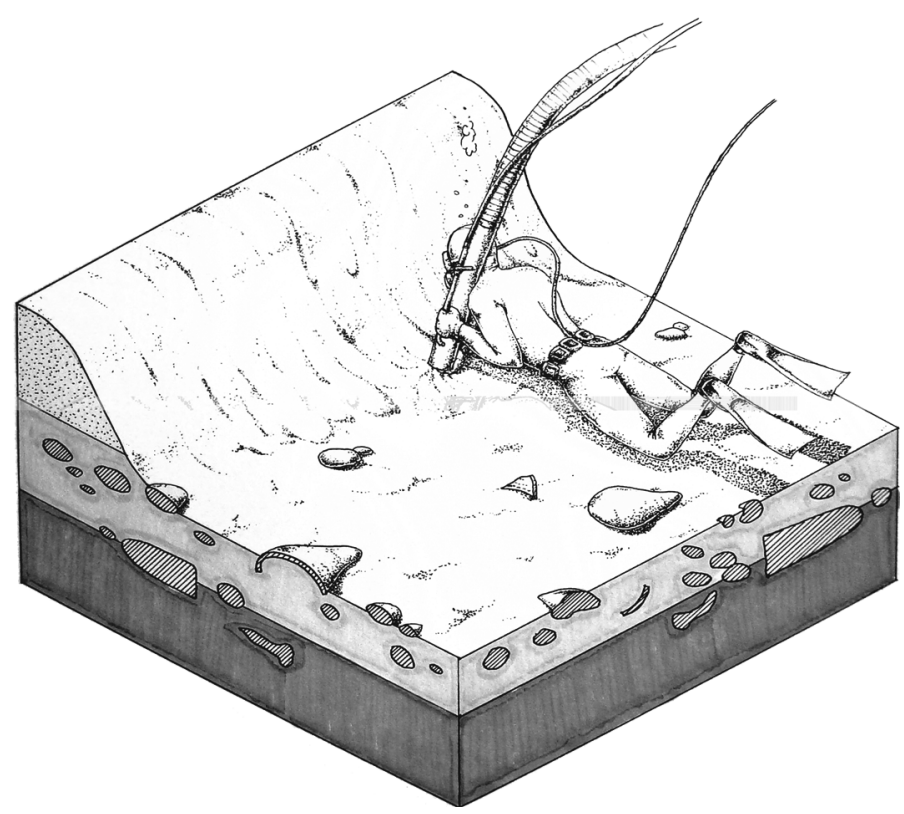

sedimento sugado é conduzido a uma distância de 14 metros da área de escavação, para uma caixa coletora metálica estruturada com cantoneiras galvanizadas e fechada por telas de diferentes tamanhos para conter as evidências arqueológicas e descartar o sedimento (Fig. 14). Nem sempre é possível evitar a sucção de pequenos artefatos, como contas de colar, que às vezes são abanados para o airlift (a baixa pressão de ar comprimido aplicado no registro arqueológico raramente causou dano aos artefatos). A caixa coletora é dividida em duas partes, com dois tamanhos de malha das peneiras que a envolvem. A parte superior possui paredes de chapa de aço com furos de 4,8 mm de diâmetro, e a

maior diâmetro, é remover a camada estéril sobre o sítio arqueológico. Sua função secundária, com canos de menor diâmetro e com fluxo de ar comprimido com baixa potência, é auxiliar na remoção cuidadosa dos sedimentos e da "poeira" diretamente sobre/entre o registro arqueológico, evitando tocar e mover os artefatos (Murphy 1997; Green 2004:253-256). O parte inferior tem paredes de chapa de aço galvanizada com furos de $3 \mathrm{~mm}$ de diâmetro. Entre as duas partes há uma tela de malha de aço galvanizado $25 \times 25 \mathrm{~mm}$. A caixa fica sobre um flutuador, recebendo o material sugado pelo airlift. Quando cheias, são levadas para terra, onde é feita triagem para separar: 1) fragmentos de conchas de moluscos; 2) biodetritos; 3) 
fragmentos de madeira, carvão, couro, seixos do lastro e concreções; 4) matéria orgânica; 5) fragmentos de cerâmica; 6) pequenos artefatos; 7) lixo moderno; 8) fragmentos de ossos de peixes e cetáceos; 9) organismos bentônicos (são separados exemplares para classificação e análise).

Após a remoção dos sedimentos os artefatos e objetos considerados mais relevantes são marcados e catalogados com etiquetas acrílicas brancas com um código de controle. Os demais objetos, como lastro e fragmentos cerâmicos, são transferidos para caixas específicas com o número da quadrícula e transportados para o laboratório. Artefatos e objetos pequenos são colocados em embalagens apropriadas para leválos ao laboratório e sua posição é marcada no mapa da escavação. Geralmente, dependendo do horário da escavação e das condições climáticas, os artefatos e objetos mais frágeis são removidos antes do registro, visando manter sua integridade, mas sua posição é marcada no mapa da escavação. Nessa etapa cada objeto recebe a primeira parte do seu código de tombo, correspondente ao número da quadrícula.

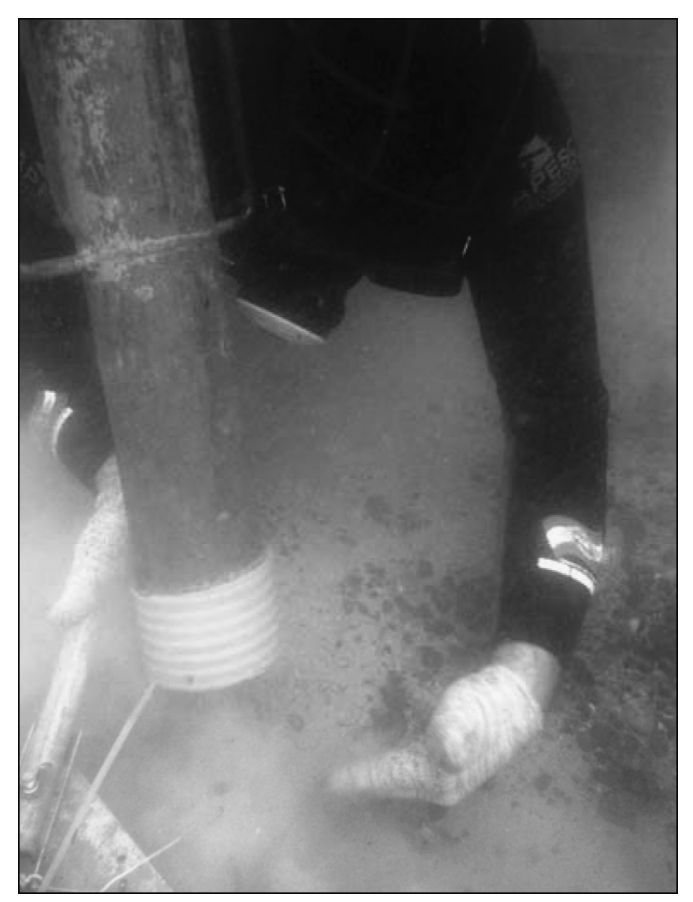

Fig. 18. Uso do airlift e abano manual.

\section{Conclusão}

O objetivo do PAS é criar as bases necessárias para a construção de um Museu de Arqueologia, História e Cultura Marítima de Santa Catarina, dedicado à pesquisa e a preservação da cultura material e das tradições locais. A tentativa de despertar o interesse pela preservação, tanto da população local, quanto dos inúmeros turistas da Praia dos Ingleses, foram objetivos desenvolvidos desde os primeiros dias no centro de visitação ${ }^{8}$ aberto na base de pesquisas na Praia dos Ingleses. Mesmo sem propaganda, o PAS recebeu mais de vinte mil visitantes na base de pesquisas da praia dos Ingleses, incluindo grupos de alunos e professores de várias escolas, oferecendo exposição guiada e apresentação de vídeo. Também realizou exposição itinerante em eventos acadêmicos, culturais e turísticos; palestrou em escolas e salões comunitários. Distribuiu milhares de folders e o gibi didático de onze páginas sobre os procedimentos da arqueologia subaquática para o público de até 13 anos, intitulado a "As aventuras da turma do projeto" (Fig. 19). O PAS também tem por objetivo criar uma linha de publicações nas temáticas do Museu, dirigidas ao meio acadêmico e à divulgação científica, com trabalhos próprios ou apoiando a iniciativa de pesquisadores do passado de Santa Catarina e Brasil meridional. A primeira publicação apoiada é um livro de 1.500 páginas em 3 volumes, de Amílcar D’Avila de Mello (2005), intitulado Expedições e Crônicas das Origens - Santa Catarina na era dos descobrimentos geográficos (Lei Rouanet e patrocínio da Petrobras).

O PAS é um projeto que começou fora da academia, desenvolvido por estudiosos amadores da Arqueologia que criaram uma ONG para fomentar a pesquisa. Posteriormente, passou a contar com um arqueólogo profissional e criou um convênio de colaboração científica com a Universidade do Vale do Itajaí - UNIVALI. Em todas as suas fases, o PAS sempre procurou

(8) Inscrito no Cadastro Nacional de Museus/MinC (ofício CT/DEMU n. 669/06, 26/10/2006). 


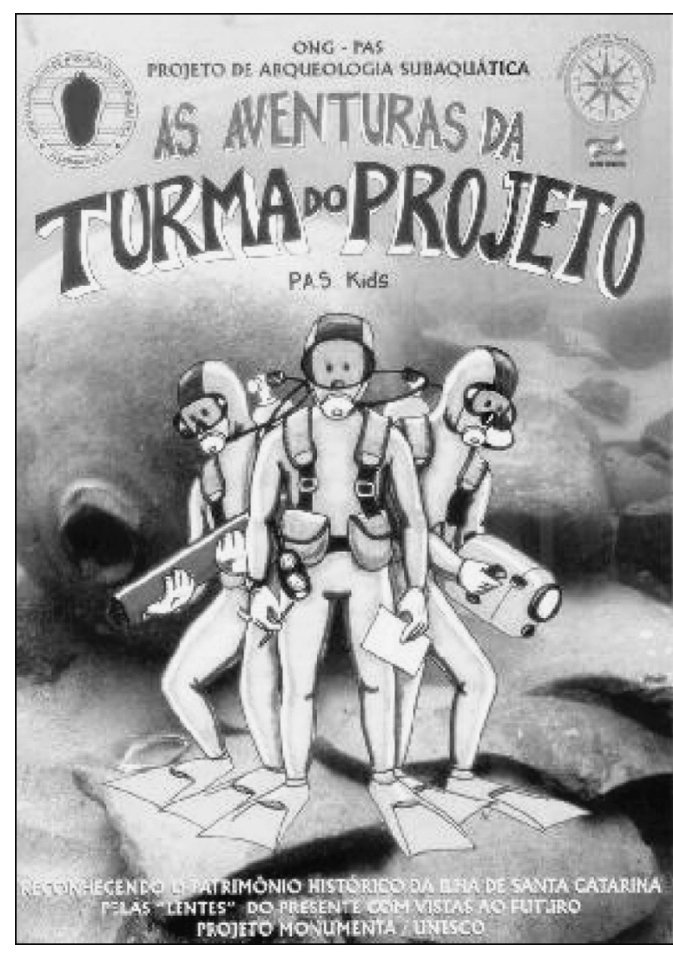

Fig. 19. Material didático.

aplicar os melhores padrões técnicos para orientar a pesquisa de campo, a curadoria e a análise das peças, em procedimentos reconhecidos e aprovados por diversos servidores do IPHAN que várias vezes fiscalizaram in loco as atividades na praia dos Ingleses e na UNIVALI.

Os resultados da escavação e os achados estão constituindo uma grande coleção de artefatos e outras evidências do século XVII, que certamente será uma das mais relevantes reunidas em um museu brasileiro. Sua análise está em andamento e diversas publicações científicas estão sendo preparadas. A curadoria das peças encontra-se em diversas fases, desde a dessalinização, o tratamento físico-químico e reconstrução (no caso das vasilhas cerâmicas), até a pesquisa da função, tecnologia de produção, origem geográfica e contexto histórico. Além dos artefatos que apresentamos acima, resgatamos outros que representam a efetiva presença dos ingleses, como uma tampa de pewter com signos heráldicos da Rosa Tudor, símbolo típico da realeza britânica e que reforçam a hipótese de que o naufrágio é o barco de Frins (Fig. 20).

Por fim, acentuando a relevância do significado histórico do sítio arqueológico da Praia dos Ingleses, é grande a probabilidade de ser o barco arribado por Thomas Frins em 1687. Seria uma conexão direta com as pessoas que fundaram o núcleo colonial do Desterro, origem da atual Florianópolis. E, posteriormente, em 1689, com os eventos que levaram à morte de Francisco Dias Velho, fundador do assentamento, por vingança dos danos que Frins sofreu. Esse ato interrompeu o desenvolvimento do Desterro por mais de 20 anos, até 1711, quando recomeçou o fluxo de colonos e a ocupação da área.

Para consolidar essa conexão e confirmar que se trata do barco de Thomas Frins, é preciso ampliar a base de dados do sítio arqueológico Praia dos Ingleses 1 e finalizar o levantamento das fontes escritas. A conclusão da análise do lastro será decisiva para traçar as rotas e paradas da embarcação. O mesmo quanto às botijas, cuja análise da pasta poderá auxiliar na definição da região de origem, pelo menos se eram européias, americanas ou de ambos os continen-

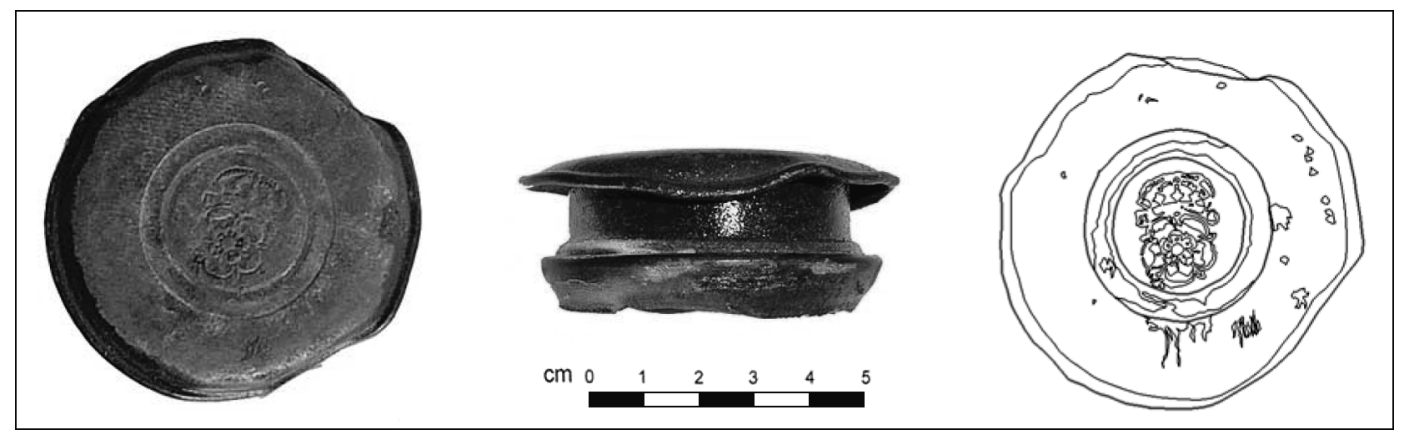

Fig. 20. Restituição fotogramétrica da tampa de pewter com a Rosa Tudor. 
tes. O estudo do casco e dos seus componentes poderá indicar sua data e local de construção, de reformas e ampliar os elementos que demonstram a tecnologia naval espanhola. A análise do conjunto de artefatos também é importante, tanto para o reconhecimento de cada peça, quanto para auxiliar no estudo das rotas percorridas pela embarcação. As fontes escritas terão peso importante nessa etapa. Será fundamental encontrar as listas de tripulantes dos barcos que deixaram a Virginia e a Inglaterra em 1683. Mas também é necessário encontrar o nome dos ingleses que atravessaram o Panamá em 1685 com o capitão Townsley, com o objetivo de encontrar notícias sobre Thomas Frins (inclusive se o nome possui essa grafia). As fontes espanholas, tanto em Sevilha, quanto na América, poderão dar informações sobre o barco, exatamente quando e onde ele foi construído e, depois de capturado, em quais ações piráticas tomou parte na costa do antigo vice-reino do Peru e do Atlântico.

\section{Agradecimentos}

Ao Governo de Estado de Santa Catarina, especialmente ao empenho do Governador Luiz Henrique da Silveira. À FAPESC, pelos recursos para o projeto. À Marinha do Brasil, pelo apoio e avaliação rigorosa. A Cyro Corrêa Lyra e aos demais servidores do IPHAN, pelo apoio e fiscalização em diversos momentos. A Narbal Corrêa, pela inestimável contribuição aos primeiros tempos do PAS. Ao Laboratório de Oceanografia Costeira da UFSC, pelo suporte à pesquisa geológica do mestrado de Maurício Marino. A Amílcar D’Avila de Mello, pelas várias idéias e sugestões. A Márcia Arcuri, Fabíola Andréa Silva e Lúcio Menezes Ferreira pelas sugestões e revisão do texto. Aos diversos membros e voluntários da ONG PAS, especialmente César Todescat, pelo incansável trabalho e bom humor. Ao Rodrigo Jordão, pelo domínio das tarefas de registro e criação das imagens eletrônicas.

NOELLI, F.S.; VIANA, A.; MOURA, M.L. Praia dos Ingleses 1: Underwater Archaeology at Santa Catarina Island, Brazil (2004/2005/2009). Revista do Museu de Arqueologia e Etnologia, São Paulo, 19: 179-203, 2009.

Abstract: This article presents the methodology and some preliminary results of the underwater archaeological research developed between two periods: March 2004-February 2005, and February-May 2009, at the Praia dos Ingleses site, Santa Catarina Island, Brazil.

Keywords: Underwater archaeology - Historical archaeology - Southern Brazil Colonial History.

\section{Referências bibliográficas}

ADAMS, J.R.

1997 South America. In J. P. Delgado (Ed.)

Encyclopaedia of Underwater Maritime Archaeology. London, The British Museum Press: 395-398.

2002 Excavation methods, underwater. In: Orser, Ch. (Ed.) Encyclopedia of
Historical Archaeology. London, Routledge: 192-196.

AISPURU, F.F.C.

2003 Modelos teóricos y métodos de cálculos para el comportamiento estructural de los navios construidos a la española y a la inglesa (1710. 1760). Madrid: Universidad Politécnica de 
Madrid/Escuela Técnica Superior de Ingenieros Navales (Tesis doctoral).

ALMEIDA, L.F.

1957 A diplomacia portuguesa e os limites meridionais do Brasil. Coimbra: Faculdade de Letras da Universidade de Coimbra.

ALMEIDA, P.T.

1980 Nobiliarquia paulistana histórica e genealógica, v. 2. São Paulo: Itatiaia/EDUSP.

AMORIM, J.

1841 Dicionário de Marinha aos oficiais da armada portugueza. Lisboa: Imprensa Nacional.

AVERY, G.

1997 Pots as packaging: The Spanish olive jar and andalusian transatlantic commercial activity, 16-1 $8^{\text {th }}$ centuries. Gainesville: University of Florida ( $\mathrm{PhD}$ thesis).

BASS, G.F.

1971 Arqueologia subaquática. Lisboa: Verbo.

1980 Marine Archaeology: a misunderstood science. Marine Science and Technology: $137-152$

BOITEUX, L.A.

1931 Paulistas em Santa Catarina seiscentista. Annaes do Museu Paulista, 4: 428-479.

BRADLEY, P.T.

1979 Maritime defense of the viceroyalty of Peru (1600-1700). The Americas, 36 (2): $155-175$.

BRUIJIN, J.R.; GAASTRA, F.S.; SHÖFFER, I. (Eds.)

1979-1987 Dutch-Asiatic shipping in the seventeenth and eighteenth centuries. The Hague: Springer, 3 vols.

BURNEY, J.

1891 A History of buccanners of the America. $2^{\text {nd }}$ ed. London: Sonnenschein.

CABRAL, O.R.

1979 Nossa Senhora do Desterro. Florianópolis: Lunardelli.

CALLAHAN, J.E.; MILLER, J.W.; CRAIG, J.R.

2001 Ballast stone studies from North Carolina Shipwreck 0003 BUI, The Queen Anne's Revenge: Hand specimen, $\mathrm{x}$ ray, petrographic, chemical, paramagnetic and $40 \mathrm{~K}-{ }^{40} \mathrm{AR}$ age results. Southeastern Geology, 40 (1):49-57.

CANABRAVA, A.P.

1944 O comércio português no rio da Prata (1580. 1640). São Paulo: Faculdade de Filosofia e Ciências Humans-USP.

CHAUNU, H.; CHAUNU, P.

1955-1960 Séville et l'Atlantique (1504-1650). Paris: S.E.V.P.E.N. (École Pratique dês HautesÉtudes). 8v.
CLAYTON, L.A.

1974 Local Initiative and Finance in Defense of the Viceroyalty of Peru: The Development of Self- Reliance. The Hispanic American Historical Review, 54(2): 284-304.

COELHO, M.J.A.

1856 Memória histórica da Província de Santa Catharina. Florianópolis: Typographia Desterrense.

CRAHAN, M.E.

1971 The administration of Don Melchor de Navarra y Rocafull, Duque de La Palata: Viceroy of Peru, 1681-1689. The Americas, 27 (4):389-412.

DAMPIER, W.

1702 A new voyage round the world. $2^{\text {nd }} \mathrm{ed}$. London: James Knapton. vol 1.

DAVIES, K.G.

1999 The Royal African Company. London: Taylor \& Francis.

DEAN, M.

1988 Guidelines on acceptable standards in Underwater Archaeology. Edimburg: Scottish Institute of Maritime Archaeology.

DELGADO, J.; STANIFORTH, M.

2002 Underwater Archaeology. In: The encyclopedia of life support systems. Paris: UNESCO. (http://www.eolss.co.uk/).

DOMINGUES, M.

1973 A Colônia do Sacramento e o sul do Brasil. Porto Alegre: Sulina.

ELTIS, D.E.

2000 The rise of African slavery in the Americas. Cambridge: Cambridge University Press.

ELTIS, D.E.; BEHRENDT, S.D.; RICHARDSON, D. KLEIN, H.S.

1999 The trans-Atlantic slave trade. A database on CD-ROM. Cambridge: Cambridge University Press.

FARACO, K.R.

2002 Comportamento monfodinâmico e sedimentológico da Praia dos Ingleses - Ilha de Santa Catarina - SC, durante o periodo de 1996-2001.

Florianópolis: Dissertação de Mestrado (Programa de Pós-Graduação em Geografia/UFSC).

GARRISON, E.G.; GIAMMONA, C.P.; JOBLING, J.; TRIPP, A.R.; WEINSTEIN, E.N.; WOLFF, G.A.

1989 A eighteenth-century ballast pile site, Chandeleur Island, Louisiana. An instrumental and archaeological study. New Orleans: OCS Study/MMS 89-0092. U.S. Dept. of the Interior, Minerals Mgmt. Service, Gulf of Mexico OCS Regional Office. 
GAWRONSKI, J.H.G.

2002 VOC Shipwrecks. In: Orser, Ch. (Ed.) Encyclopedia of Historical Archaeology. London, Routledge: 563-566.

GERHARD, P.

2003 Pirates of New Spain, 1575-1742. New York: Courier Dover Publications.

GODOY, J.E.P.

2007 Naus no Brasil Colônia. Brasília: Edições do Senado Federal.

GREEN, J.

2004 Maritime Archaeology. A technical handbook. $2^{\text {nd }}$ ed. San Diego: Elsevier.

GUEDES, M.J.

1975-1985 História Naval Brasileira. Rio de Janeiro: SDGM. 10v.

GUINOTE, P.; FRUTUOSO, E. LOPES, A.

1998 Naufrágios e outras perdas na "carreira das Índias". Séculos XVI e XVII. Lisboa: GTMECDP.

HINGLEY, D.K.

2004 The Progreso Basin Province of northwestern Peru and southwestern Ecuador: Neogene and CretaceousPaleogene Total Petroleum Systems. Reston: U.S. Geological Survey.

JAMES JR, S.R.

1988 A reassessment of the chronological and typological framework of the Spanish olive jar. Historical Archaeology, 22 (1): 43-66.

LAMB, W.R.

1988 The provenance of ballast stone from the Molasses Reef Wreck. College Station: Texas A \& M University (Masters thesis).

LANE, K.E.

1998 Pillaging the Empire: Piracy in the Americas, 1500-1750. New York: M. E. Sharpe.

LORENZO, J.; MURGA, G.; FERREIRO, M.

1864 Diccionario Marítimo Español. Madrid: T. Fortanet.

LUSSAN, R.

1856 The History of buccanners of the America; containing detailed accounts of those bold and daring freebooters chiefly along the Spanish main, and the West Indies, and in the Great South Sea. Boston: Sanborn, Carter \& Bazin.

MARINO, M.V.

2006 Caracterização morfossedimentar da plataforma continental interna da enseada dos Ingleses - SC, como apoio à Arqueologia. Florianópolis: Dissertação de Mestrado (Programa de Pós-Graduação em Geografia/UFSC).
MARSDEN, P.

1994 A comparative look at records of twenty years of wreck archaeology. The International Journal of Nautical Archaeology, 23 (2):155-158.

MARTIN, C.J.M.; MARTIN, E.A.

2002 An underwater photomosaic technique using Adobe Photoshop. International Journal of Nautical Archaeology, 31 (1):137-147.

MAURO, F.

1980 Expansão européia (1600-1870). São Paulo: Pioneira/Edusp.

1997 Portugal, o Brasil e o Atlântico (1570-1670). Lisboa: Estampa. 2v.

MELLO, A.D.

2005 Expedições e Crônicas das Origens - Santa Catarina na era dos descobrimentos geográficos. Florianópolis: Expressão. 3 vols.

MENDES, J.C.

1992 Elementos de estratigrafia. São Paulo: T.A. Queiroz.

MOLINA, R.A.

1966 Las primeras experiencias comerciales del Plata. El comercio marítimo (1580-1700). Buenos Aires: Dorrego.

MUCKELROY, K.

1978 Maritime Archaeology. Cambridge: Cambridge University Press.

MURPHY, L.E.

1997 Airlift. In: Delgado, J.P. (Ed.) Encyclopaedia of Underwater Maritime Archaeology. London, The British Museum Press: 22.

NAVARRETE, M.F.

1831 Diccionario Marítimo Español. Madrid: Imprenta Real.

NOELLI, F.S.

s.d. Inventário de barcos que aportaram ou passaram ao largo da ilha de Santa Catarina, Brasil. 50p.

PAESIE, R.

2008 Lorrendrayen op Africa. De illegale goederenen slavenhandel op West-Afrika tijdens het achttinde-eeuwse handelsmonopolie van de West-Indische Compagnie, 1700-1734. Leiden: Universiteit Leiden.

PIAZZA, W.F.

1983 Santa Catarina: Sua História. Florianópolis: UFSC/Lunardelli.

RAWLEY, J.A.

2003 The port of London and the eighteenthcentury slave-trade. Historians, sources and a reappraisal. In: Rawley, J.A. (Ed.) London, metropolis of the slave 
trade. Columbia, University of Missouri Press: $18-39$.

RAWLEY, J.A.; BEHRENDT, S.D.

2005 The transatlantic slave trade: a history. $2^{\text {nd }}$ ed. Lincoln: University of Nebraska Press.

RICE, P.M.

1996 The Archaeology of Wine: The Wine and Brandy Haciendas of Moquegua, Peru. Journal of Field Archaeology, 23 (2): 187-204.

SCHIFFER, M.B.

1987 Formation processes of the archaeological record. Albuquerque: University of New Mexico Press.

SHEPARD, F.P.

1973 Submarine Geology. $3^{\text {th }}$ ed. New York: Harper \& Raw.

SOTOMAYOR, J.H.

1901a Carta a S. M., del gobernador de Buenos Aires, José de Herrera y Sotomayor, 4 de abril de 1688. In. Catalogo de documentos del Archivo de Índias en Sevilla referentes a la Republica Argentina - 1514/1810. Buenos Aires: Ministério de Relaciones Exteriores. p. 393.

1901b Consulta ao Consejo de Índias, del gobernador de Buenos Aires, José de Herrera y Sotomayor, 5 de abril de 1688. In. Catalogo de documentos del Archivo de Índias en Sevilla referentes a la Republica Argentina - 1514/1810.

Buenos Aires: Ministério de Relaciones Exteriores. p. 393.

VÁRZEA, V.

1985 Santa Catarina: a Ilha. Florianópolis: Ludarnelli.

VIANA, A.; CORREA, N.S.; MOURA, M.L.

2004 Projeto Arqueologia Subaquática: $\mathrm{O}$ Patrimônio Cultural Marinho do Estado de Santa Catarina. Revista do Museu de Arqueologia e Etnologia, 14: 387-391.

WAFER, L.

1903 A New Voyage and description of the Isthmus of America. Cleveland: Burrows.

WILLEY, G.R.

1966 An introduction to American Archaeology: South America. Englewood Cliffs: Prentice Hall.

ZAPATA, J.E.L.

2005 Memórias históricas, fisicas, crítico, apologéticas de la América Meridional. Lima: PUC-Peru/ Univ. Nac. de San Marcos/Inst. Francés de Estúdios Andinos. 